\title{
What do correlations tell us about anthropogenic-biogenic interactions and SOA formation in the Sacramento plume during CARES?
}

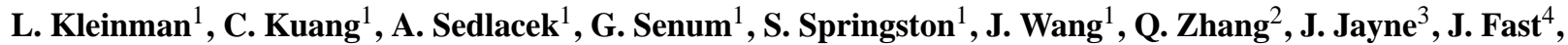 \\ J. Hubbe ${ }^{4}$, J. Shilling ${ }^{4}$, and R. Zaveri ${ }^{4}$ \\ ${ }^{1}$ Brookhaven National Laboratory, Upton, NY, USA \\ ${ }^{2}$ University of California at Davis, Davis, CA, USA \\ ${ }^{3}$ Aerodyne Research Inc., Billerica, MA, USA \\ ${ }^{4}$ Pacific Northwest National Laboratory, Richland, WA, USA
}

Correspondence to: L. Kleinman (kleinman@bnl.gov)

Received: 7 July 2015 - Published in Atmos. Chem. Phys. Discuss.: 17 September 2015

Revised: 31 December 2015 - Accepted: 14 January 2016 - Published: 15 February 2016

\begin{abstract}
During the Carbonaceous Aerosols and Radiative Effects Study (CARES) the US Department of Energy (DOE) G-1 aircraft was used to sample aerosol and gas phase compounds in the Sacramento, CA, plume and surrounding region. We present data from 66 plume transects obtained during 13 flights in which southwesterly winds transported the plume towards the foothills of the Sierra Nevada. Plume transport occurred partly over land with high isoprene emission rates. Our objective is to empirically determine whether organic aerosol (OA) can be attributed to anthropogenic or biogenic sources, and to determine whether there is a synergistic effect whereby OA concentrations are enhanced by the simultaneous presence of high concentrations of carbon monoxide (CO) and either isoprene, MVK + MACR (sum of methyl vinyl ketone and methacrolein), or methanol, which are taken as tracers of anthropogenic and biogenic emissions, respectively. Linear and bilinear correlations between OA, $\mathrm{CO}$, and each of three biogenic tracers, "Bio", for individual plume transects indicate that most of the variance in OA over short timescales and distance scales can be explained by CO. For each transect and species a plume perturbation, (i.e., $\triangle \mathrm{OA}$, defined as the difference between 90th and 10th percentiles) was defined and regressions done amongst $\Delta$ values in order to probe day-to-day and location-dependent variability. Species that predicted the largest fraction of the variance in $\triangle \mathrm{OA}$ were $\Delta \mathrm{O}_{3}$ and $\Delta \mathrm{CO}$. Background OA was highly correlated with background methanol and poorly correlated
\end{abstract}

with other tracers. Because background OA was $\sim 60 \%$ of peak OA in the urban plume, peak OA should be primarily biogenic and therefore non-fossil, even though the day-today and spatial variability of plume OA is best described by an anthropogenic tracer, $\mathrm{CO}$. Transects were split into subsets according to the percentile rankings of $\triangle \mathrm{CO}$ and $\Delta$ Bio, similar to an approach used by Setyan et al. (2012) and Shilling et al. (2013) to determine if anthropogenic-biogenic (A-B) interactions enhance OA production. As found earlier, $\triangle \mathrm{OA}$ in the data subset having high $\triangle \mathrm{CO}$ and high $\triangle \mathrm{Bio}$ was several-fold greater than in other subsets. Part of this difference is consistent with a synergistic interaction between anthropogenic and biogenic precursors and part to an independent linear dependence of $\triangle \mathrm{OA}$ on precursors. The highest values of $\Delta \mathrm{O}_{3}$, along with high temperatures, clear skies, and poor ventilation, also occurred in the high $\Delta \mathrm{CO}-$ high $\Delta \mathrm{Bio}$ data set. A complicated mix of A-B interactions can result. After taking into account linear effects as predicted from low concentration data, an A-B enhancement of OA by a factor of 1.2 to 1.5 is estimated.

\section{Introduction}

In order to explain the amount of organic aerosol (OA) as well as its spatial distribution and ${ }^{14} \mathrm{C}$ content, several groups have advanced the hypothesis that the secondary component 
(SOA) is derived from biogenic precursors but its formation depends on interactions between urban anthropogenic emissions and a larger, geographically dispersed pool of biogenic emissions, hereinafter referred to as A-B interactions (de Gouw et al., 2005; Weber et al., 2007; Goldstein et al., 2009; de Gouw and Jimenez, 2009; Carlton et al., 2010; Worton et al., 2011; Xu et al., 2015). A-B interactions lie at the intersection of two problems. First is an explanation of unexpectedly high concentrations of OA, which are most prominently noticed downwind of urban areas (e.g., Volkamer et al., 2006; Kleinman et al., 2008; Matsui et al., 2009). Second is the finding that a high fraction of OA consists of nonfossil carbon of biogenic origin, even downwind of urban areas (Schichtel et al., 2008; Marley et al., 2009; Hodzic et al., 2010; Zotter et al., 2014).

Progress has been made on the problem of models predicting lower OA than observed. Older models (ca. pre 2005) are now recognized to contain a limited set of aerosol precursors and aerosol formation mechanisms. Some part of the gap between observations and theory can be closed using updated models that contain new categories of anthropogenic compounds, chemical mechanisms, and physical interactions (e.g. Robinson et al., 2007; Hodzic et al., 2010). In order to agree with ${ }^{14} \mathrm{C}$ measurements, the gap has to be closed with a significant fraction of non-fossil carbon, which brings us back to the possibility of A-B interactions.

Evidence for, and mechanisms of, A-B interactions have been reviewed by Hoyle et al. (2011). Pertinent findings are that (1) the major source of volatile organic compounds (VOCs), globally and in many well-studied regions, such as the southeastern US and Canadian boreal forest, is biogenic (e.g., Guenther et al., 1995; Goldstein et al., 2009; Slowik et al., 2010), (2) large biogenic emission rates and SOA yields are a possible cause for the high fraction of non-fossil carbon found in the summer in many locations (Schichtel et al., 2008; Hodzic et al., 2010), including those that are nominally urban (Weber et al., 2007; Marley et al., 2009), and (3) there are realistic mechanisms whereby biogenic SOA yields depend on the presence of anthropogenic pollutants (Carlton et al., 2010). The latter include effects of anthropogenic pollutants on oxidant levels and consequently on biogenic VOC oxidation rates (Kanakidou et al., 2000), increased partitioning of biogenic VOC oxidation products to the aerosol phase because the aerosol volume, including associated water, available for partitioning is increased by an anthropogenic component (Carlton et al., 2010; Carlton and Turpin, 2013), aqueous phase reactions (Ervens et al., 2011), and effects of sulfate on aerosol phase chemistry (Xu et al., 2015). Explanations of non-fossil carbon based on A-B interactions are constrained by the observation that the difference between modeled and observed OA concentration generally decreases as anthropogenic influence decreases (Tunved et al., 2006; Chen et al., 2009; Hodzic et al., 2010; Slowik et al., 2010)
In multiple studies it has been found that OA, SOA, and/or WSOC (water soluble organic carbon; demonstrated to be a surrogate for SOA) are highly correlated with anthropogenic tracers. High correlations have been observed even at locations where it is suspected that much if not most SOA is biogenic. In a study of the Atlanta region, aircraft flights over the urban core established that WSOC is proportional to carbon monoxide (CO), while surface observations of aerosol ${ }^{14} \mathrm{C}$, also in the urban core, established that 70-80\% of WSOC was non-fossil and likely biogenic (Weber et al., 2007). While there was a high correlation between WSOC and $\mathrm{CO}$ in Atlanta, similar to that observed in the New York City metropolitan region (Sullivan et al., 2006), there was no clear linkage between WSOC and biogenic VOCs. At the Blodgett Forest Research Station, located $25 \mathrm{~km}$ downwind from the Carbonaceous Aerosols and Radiative Effects Study (CARES) sampling region, OA was observed to be correlated with $\mathrm{CO}\left(R^{2}=0.79\right)$ but based on ${ }^{14} \mathrm{C}$ filter samples it was determined that the majority of aerosol carbon was non-fossil from biogenic sources (Worton et al., 2011). Although high correlations between OA and biogenic VOCs have been reported (e.g. Slowik et al., 2010), it is more typical that in regions with an urban influence, correlations are low and in general do not suggest a relation between SOA and biogenic precursors. In a set of global calculations having the objective of satisfying the dual constraints of matching observations of OA concentration and ${ }^{14} \mathrm{C}$ content, it was found that the best of many mechanisms considered was one in which the geographic distribution of OA followed that of anthropogenic $\mathrm{CO}$, but had a ${ }^{14} \mathrm{C}$ content appropriate to a biogenic precursor (Spracklen et al., 2011).

An objective of the CARES field campaign, conducted in June 2010, was to determine whether and to what extent the simultaneous occurrence of high concentrations of anthropogenic and biogenic compounds is associated with enhanced concentrations of OA. An overview of the field campaign is given by Zaveri et al. (2012) and a detailed description of the meteorology and emission source regions affecting the Sacramento plume provided by Fast et al. (2012). Effects of A-B interactions have been examined during the CARES campaign by Shilling et al. (2013) using aircraft data from the G-1 and by Setyan et al. (2012) using data from the rural $\mathrm{T} 1$ surface site located $40 \mathrm{~km}$ northeast of Sacramento. Both studies considered the ratio (OA - background) / ( $\mathrm{CO}$ - background) and found that this ratio increased by a factor of $\sim 3$ when an anthropogenically influenced air mass also contained high concentrations of biogenic VOCs. At a CO concentration, indicative of a significant anthropogenic impact, both studies find that OA concentrations are higher when the $\mathrm{CO}$ is accompanied by higher concentrations of biogenic VOCs.

In this study we use linear and bilinear regressions to empirically relate OA to tracer compounds of anthropogenic or biogenic origin. $\mathrm{CO}$ is used as a nearly inert tracer of anthropogenic emissions, that upon atmospheric oxidation 
lead to SOA. A comparison is made between calculations in which isoprene, methyl vinyl ketone and methacrolein (MVK + MACR), or methanol $\left(\mathrm{CH}_{3} \mathrm{OH}\right)$ were used as tracers of biogenic emissions. Isoprene and MVK + MACR, in contrast to $\mathrm{CO}$, have short atmospheric lifetimes; therefore, their presence only explicitly addresses biogenic inputs to an air mass over a few hours time span. $\mathrm{CH}_{3} \mathrm{OH}$, has a primary biogenic source and a lifetime of order 10 days (Schade and Goldstein, 2006; Wells et al., 2012) and therefore can provide information on biogenic inputs over a time span comparable to the lifetime of tropospheric aerosols.

In order to understand the roles of anthropogenic and biogenic tracers in describing SOA formation over spatial scales comparable to the Sacramento plume, correlation coefficients between OA and explanatory variables have been determined for each plume transect. For the purpose of determining the sensitivity of OA to conditions that vary over the CARES campaign, we define for each plume transect and species a background concentration and plume perturbation, $\Delta$, and use these quantities in a regression analysis amongst transects. Transects are also split into subsets having the varying combination of low and high values for $\Delta \mathrm{CO}$ and $\Delta$ isoprene, $\triangle \mathrm{MVK}+\mathrm{MACR}$ or $\Delta \mathrm{CH}_{3} \mathrm{OH}$. We find that the data subset with high concentrations of both anthropogenic and biogenic tracers has uniquely high values of $\Delta \mathrm{OA}$. This result is similar to the A-B enhancement found by Setyan et al. (2012) and Shilling et al. (2013). We consider whether the uniquely high values of $\triangle \mathrm{OA}$ can be explained by an independent linear dependence of $\triangle \mathrm{OA}$ on anthropogenic and biogenic tracers, rather than a synergistic effect.

$\mathrm{OA}$ and its anthropogenic and biogenic precursors are expected to be mutually enhanced through a common dependence on meteorological conditions (e.g. ventilation, sunlight, and temperature) occurring in pollution episodes (Goldstein et al., 2009). Such conditions promote A-B interaction and may also give rise to an altered, non-synergistic dependence of OA on precursors. Our analysis cannot distinguish between causes of enhanced OA, leading us to equate the net effect of enhanced $\mathrm{OA}$ above that expected from a bilinear model of low concentration data to an $\mathrm{A}-\mathrm{B}$ interaction. We find a high correlation between $\triangle \mathrm{OA}$ and $\Delta \mathrm{O}_{3}$ (Herndon et al., 2008; Wood et al., 2010). Studies of the dependence of $\mathrm{O}_{3}$ on meteorological factors and on anthropogenic and biogenic precursors have a long history and could yield insights on SOA production.

Although there is a high anthropogenic, high biogenic, subset that stands out as having high concentrations of $\triangle \mathrm{OA}$, most of the spatial variability of OA within a transect and $\triangle \mathrm{OA}$ amongst transect can be explained by $\mathrm{CO}$ or $\Delta \mathrm{CO}$, respectively. These observations suggest a primarily anthropogenic origin for OA produced in the Sacramento plume. In contrast, the variability of background $\mathrm{OA}$ is much better explained by background $\mathrm{CH}_{3} \mathrm{OH}$, which suggests a biogenic origin. As background $\mathrm{OA}$ is more abundant than $\mathrm{OA}$ formed in the Sacramento plume, the plume OA, though cor- relating best with $\mathrm{CO}$, is expected to have a ${ }^{14} \mathrm{C}$ signature of non-fossil, biogenic carbon. The plume composition would then resemble that observed in Atlanta (Weber et al., 2007) and that observed in the afternoon outflow from Los Angeles (Zotter et al., 2014).

\section{Experimental}

Data for the CARES field campaign including the G-1 data used in this study can be accessed from DOE's ARM (Atmospheric Radiation Measurement) Climate Research archive at http://www.archive.arm.gov. AMS (Aerosol Mass Spectrometer) and PTR-MS (Proton Transfer Reaction Mass Spectrometer) data were recorded at the instrument cycle time of 13 and $4 \mathrm{~s}$, respectively. Most other measurements were collected at $1 \mathrm{~Hz}$. Data used in this study was interpolated or averaged to a $10 \mathrm{~s}$ time base. Units for aerosol concentration are $\mu \mathrm{g} \mathrm{m}^{-3}$ at $1013 \mathrm{mb}$ and $23^{\circ} \mathrm{C}$. Trace gas abundances are expressed as mixing ratios in units of ppbv. When referring to aerosol and gas phase species collectively, the term concentration is used.

\subsection{Instruments}

The primary chemical measurements used in the regression analysis are (1) organic aerosol: designated hereinafter as OA, (2) CO: a surrogate for anthropogenic precursors of OA, (3) isoprene: $\mathrm{MVK}+\mathrm{MACR}$, and $\mathrm{CH}_{3} \mathrm{OH}$, surrogates for biogenic OA precursors, and (4) $\mathrm{O}_{3}$ : a product of OH-driven photochemistry. These species were measured using an Aerodyne HR-Tof-AMS (High-Resolution Time-of-Flight Aerosol Mass Spectrometer), a VUV (vacuum ultraviolet) resonance fluorescence detector built at BNL (Brookhaven National Laboratory), an Ionicon PTRMS (Lindinger et al., 1998), and a TEI49 (Thermo Environmental Instruments) $\mathrm{O}_{3}$ detector, respectively. An overview of instrumentation used in CARES is given in Zaveri et al. (2012).

Operational principals of the AMS are described by Canagaratna et al. (2007) and references therein. Its use on the G-1 during CARES is described by Shilling et al. (2013). In brief, the AMS on the G-1 operated in V-mode, with the duty cycle devoted entirely to determining mass, rather than massresolved particle size. A pressure controlled inlet maintained constant volumetric flow at all flight altitudes. Aerosol entered the cabin through a two stage diffuser isokinetic inlet designed by Brechtel Manufacturing with a transmission efficiency close to $100 \%$ for particles smaller than $\sim 3 \mu \mathrm{m}$. The transmission efficiency of the AMS falls off above a vacuum aerodynamic diameter $\left(d_{\mathrm{va}}\right)$ of $600 \mathrm{~nm}$ dropping to zero at $1.5 \mu \mathrm{m}$.

The PTR-MS on-board the G-1 is described by Shilling et al. (2013). Co-detection of compounds isobaric to isoprene, $\mathrm{MVK}+\mathrm{MACR}$, and $\mathrm{CH}_{3} \mathrm{OH}$ was thought to be minor in the 


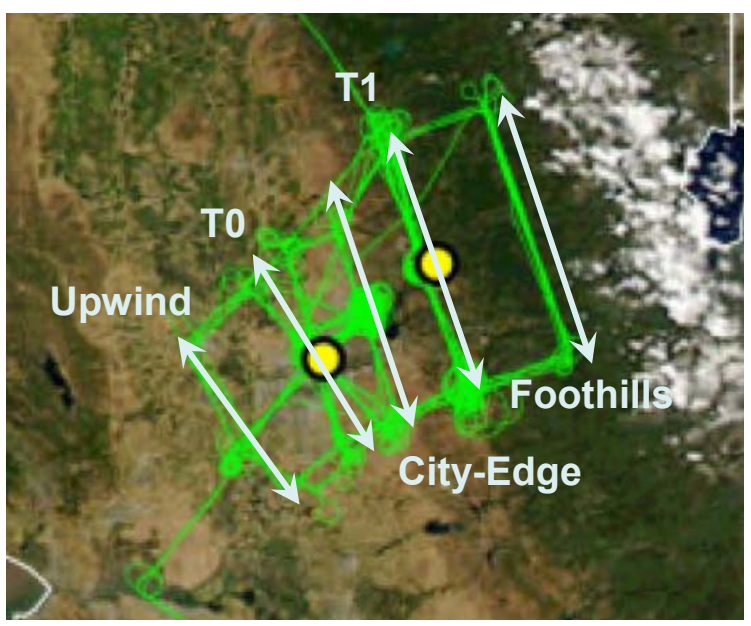

Figure 1. Map of sampling region, showing composite ground track for SW flights. Five transects more or less perpendicular to the boundary layer wind direction are indicated. Adapted from Zaveri et al. (2012).

CARES domain. Mixing ratios of monoterpenes were typically close to the limit of detection and therefore could not be used to identify air masses influenced by biogenic emissions.

\subsection{Flights}

There were 22 research flights in CARES. Only boundary layer portions of flights with SW winds are considered here. Turbulent kinetic energy dissipation rate and the standard deviation of vertical velocity were used to distinguish the convective boundary layer from the more quiescent free troposphere. Flights selected make a relatively homogeneous set in terms of sampling locations. There were 14 such flights, one of which (623a) is not included in this analysis because of problems with the $\mathrm{CO}$ measurement. Flights are listed in Table 1. A composite ground track for the SW flights is given in Fig. 1. Proceeding in the direction of the wind, transects are identified as Upwind, T0, City-Edge, T1, and Foothills. Transects $\mathrm{T} 0$ and $\mathrm{T} 1$ passed over the similarly named ground sites. These five flight segments are more or less perpendicular to the wind direction. Unfortunately there are no pairs of compounds that can be used for photochemical age. Organic aerosol O to C ratios reported by Shilling et al. (2013) are in a narrow range and thus not likely to provide information on aging.

Figure 1 shows a change in terrain color from brown to green at the $\mathrm{T} 1$ transect, indicating more vegetation to the east, which coincides with emission inventory estimates of higher isoprene emissions rates (Fast et al., 2012; Zaveri et al., 2012). The Foothills transect is at the western edge of a $20-25 \mathrm{~km}$ band of oak woodlands. Still further to the northeast there is a shift in vegetation, so that at the Blodgett Forest research station, $75 \mathrm{~km}$ from Sacramento, monoterpenes are the dominate source of SOA (Dreyfus et al., 2002).
Table 1. Flights used in study.

\begin{tabular}{ll}
\hline Flight & Time (PST; hh:mm) \\
\hline 606a & $09: 35-12: 42$ \\
$606 \mathrm{~b}$ & $14: 29-17: 14$ \\
$608 \mathrm{a}$ & $07: 56-11: 12$ \\
$608 \mathrm{~b}$ & $14: 24-17: 47$ \\
$615 \mathrm{a}$ & $07: 57-11: 01$ \\
$615 \mathrm{~b}$ & $13: 50-17: 07$ \\
$619 \mathrm{a}$ & $14: 26-17: 29$ \\
$623 \mathrm{~b}$ & $14: 25-17: 25$ \\
$624 \mathrm{a}$ & $07: 56-11: 11$ \\
$624 \mathrm{~b}$ & $14: 25-17: 12$ \\
$627 \mathrm{a}$ & $09: 24-12: 47$ \\
$628 \mathrm{a}$ & $08: 23-11: 33$ \\
$628 \mathrm{~b}$ & $14: 21-16: 42$ \\
\hline
\end{tabular}

\subsection{Plumes}

On many flights the Sacramento plume was crossed multiple times at the same location. If these crossings were consecutive, at the same altitude, and within the boundary layer, they were grouped together for the purpose of calculating concentrations and for regression analysis. If plume crossings were separated in time or were at different altitudes they constituted separate data entries. Henceforth, the term plume crossing will refer to individual crossings whilst the term transect collapses consecutive crossings (that meet criteria given above) into a single entity. As listed in Table 2, there were a total of 83 plume crossings that made up 66 plume transects. The number of $10 \mathrm{~s}$ data points in a single plume crossing is about 60. For each transect, frequency distributions for aerosol and trace gas concentration were determined. Background concentrations are operationally defined by the 10th percentile. Perturbations above background were calculated as the difference between the 90th and 10th percentile of concentration and are denoted by the symbol $\Delta$.

\section{Data analysis}

In our analysis of the G-1 data set we consider variations in OA observed along a plume transect and a larger-scale variability that includes the effects of day-to-day changes in meteorology. Variations in OA are correlated with anthropogenic and biogenic explanatory variables, which are surrogates for the actual compounds that form SOA.

\subsection{Tracers}

$\mathrm{CO}$ was used as a tracer of anthropogenic emissions. It is almost inert over the timescale for forming SOA and its emission sources are either co-located with sources of VOCs that can form SOA or follow a common spatial pattern such as population density. Proceeding downwind from a high emis- 
sion region, dilution causes concentrations of $\mathrm{CO}$ and $\mathrm{OA}$ to decrease. SOA is formed from photochemical processing of emitted pollutants while changes to $\mathrm{CO}$ aside from dilution are relatively minor (in the absence of downwind emission sources) causing the ratio $\mathrm{OA} / \mathrm{CO}$ to increase with photochemical age (Sullivan et al., 2006; Weber et al., 2007; de Gouw et al., 2005, 2008; Kleinman et al., 2008). Formation of $\mathrm{CO}$ from oxidation of biogenic compounds is discussed by Shilling et al. (2013) and thought to be a small fraction of anthropogenic emissions for flights discussed herein. A comparison of regression slopes measured on $\mathrm{T} 0$ transects with those measured on $\mathrm{T} 1$ transects shows considerable variability that averages out to a $54 \%$ increase downwind, less than seen in other urban plumes. OA to $\mathrm{CO}$ ratios observed over $\mathrm{T} 0$ are several-fold greater than the lowest values observed in other urban centers where primary emissions are important (calculated from Zhang et al., 2005, 2007). This is in agreement with observations from T1 that show $90 \%$ of OA is secondary (Setyan et al., 2012) and observations from the G-1 (Shilling et al., 2013) that show only minor changes in $\mathrm{O}$ to $\mathrm{C}$ ratios as a function of downwind distance. A factor contributing to a low range in processing is that the $\mathrm{T} 0$ site is $14 \mathrm{~km}$ downwind of the urban center and therefore OA observed on the T0 transect is already somewhat aged (Fast et al., 2012). Also, Sacramento urban emissions are spread out over a fetch nearly equal to the T0 to $\mathrm{T} 1$ distance, thereby blurring the distinction between urban and downwind chemistry. An $\mathrm{O}$ to $\mathrm{C}$ signal for fresh emissions is further diluted by aged background aerosol from the San Francisco Bay area or from recirculation of the prior days plume into the residual layer over Sacramento.

Isoprene, first generation isoprene oxidation products MVK + MACR, and methanol were used as surrogate compounds to represent emitted biogenic VOCs responsible for SOA formation. As the atmospheric lifetime of isoprene with respect to $\mathrm{OH}$ oxidation is of an order of $1 \mathrm{~h}$ (at $\mathrm{OH}=3 \times 10^{6} \mathrm{molec}^{-3}$ ), its presence in the atmosphere reflects local conditions rather than the longer time span over which SOA production is thought to occur. Because the reaction of MVK+MACR with $\mathrm{OH}$ is $\sim 3$ to 4 times slower than isoprene, atmospheric residence times are closer to the timescale for transport of the Sacramento plume within our sampling region. Transport times from the Sacramento urban center to $\mathrm{T} 1$ have been calculated to be 2 to $8 \mathrm{~h}$ from WRF-Chem simulations (Fast et al., 2012). However, under high $\mathrm{NO}_{x}$ conditions such as found in the photochemically active regions of an anthropogenic plume, the formation of OA from isoprene emissions proceeds primarily from second and higher generation oxidation products rather than directly from MVK + MACR (Ng et al., 2006; Carlton et al., 2009). While there might not be a direct link between concurrently measured isoprene or MVK + MACR and SOA, the occurrence of high mixing ratios of isoprene and its oxidation products can indicate a potential for future SOA production or be a general indicator that meteorological con-
Table 2. Number of plume crossings and transects.

\begin{tabular}{lrr}
\hline Location & \multicolumn{2}{c}{ Number } \\
\cline { 2 - 3 } & Plume crossings & Transects \\
\hline Upwind & 11 & 10 \\
T0 & 25 & 22 \\
City-edge & 15 & 12 \\
T1 & 26 & 17 \\
Foothills & 6 & 5 \\
\hline
\end{tabular}

ditions such as temperature, sunlight, ventilation, and wind direction are favorable for the occurrence and accumulation of biogenic VOCs. Methanol, in contrast, addresses source attribution for biogenic aerosol in much the same way as $\mathrm{CO}$ is used as a tracer of anthropogenic SOA precursors. The atmospheric lifetime of methanol is $\sim 10$ days and while not an SOA precursor, it is co-emitted with biogenic VOCs that are. Under conditions prevailing in the experimental area it is expected that the source of methanol is almost entirely biogenic (Wells et al., 2012). Emission rates for $\mathrm{CH}_{3} \mathrm{OH}$, especially the biogenic component from new leaf production, have a pronounced seasonal variability peaking in the spring and early summer (Schade and Goldstein, 2006; Wells et al., 2012), nearly coincident with the CARES field campaign. In other regions and at other times, a greater fraction of $\mathrm{CH}_{3} \mathrm{OH}$ may derive from maritime sources, forest fires, or peroxy radical combination reactions, which could compromise the utility of $\mathrm{CH}_{3} \mathrm{OH}$ as a tracer of biogenic aerosol precursors.

\subsection{Regression analysis}

A series of single variable and multi-variable regressions were performed using time series measurements for each of 66 transects. M1 to M5 designate the models used. Standardized variables, indicated with a subscript $S$, have zero mean and unit standard deviation. The term "Bio" designates a tracer of biogenic emission, which in this study is isoprene, $\mathrm{MVK}+\mathrm{MACR}$, or $\mathrm{CH}_{3} \mathrm{OH}$. Models M1-M4 are based on $\mathrm{CO}$ and Bio as explanatory variables. M4 uses a bilinear combination of $\mathrm{CO}$ and Bio and $\mathrm{M} 3$ measures multicollinearity, the extent to which the two explanatory variables, CO and Bio, are correlated. M5 is a linear relation between $\mathrm{OA}$ and $\mathrm{O}_{3}$.

The same models were used to compare backgrounds and concentration perturbations (e.g. $\triangle \mathrm{OA}, \Delta \mathrm{CO}$ ) amongst transects. M1 to M5 are defined by

M1 $\mathrm{OA}=a_{1}+B_{1} \mathrm{CO}$

M2-Bio $\mathrm{OA}=a_{2}+B_{2 \text { BIOBio }}$

M3-Bio $\quad \mathrm{CO}=a_{3}+B_{3}$ BIOBio

M4-Bio $\mathrm{OA}=a_{4}+B_{4} \mathrm{CO} C O+B_{4 \mathrm{BIO}} \mathrm{Bio}$ 
Table 3. Backgrounds averaged over transects at five locations.

\begin{tabular}{|c|c|c|c|c|c|c|}
\hline \multirow[t]{2}{*}{ Transect } & \multicolumn{6}{|c|}{ Background* } \\
\hline & OA & $\mathrm{CO}$ & Isoprene & $\begin{array}{r}\text { MVK } \\
+ \text { MACR }\end{array}$ & $\mathrm{CH}_{3} \mathrm{OH}$ & $\mathrm{O}_{3}$ \\
\hline Upwind & 3.9 & 127 & 0.29 & 0.18 & 4.7 & 35 \\
\hline T0 & 4.1 & 132 & 0.30 & 0.13 & 4.6 & 41 \\
\hline City-edge & 4.8 & 133 & 0.26 & 0.11 & 4.4 & 53 \\
\hline $\mathrm{T} 1$ & 5.3 & 134 & 1.1 & 0.97 & 5.5 & 50 \\
\hline Foothills & 4.2 & 133 & 1.9 & 1.5 & 5.1 & 57 \\
\hline
\end{tabular}

$\mathrm{M}_{\mathrm{S}}-\mathrm{Bio} \quad \mathrm{OA}_{\mathrm{S}}=\beta_{4 \mathrm{COCO}_{\mathrm{S}}}+\beta_{4 \mathrm{BIO}} \mathrm{BioS}_{\mathrm{S}}$

M5 $\mathrm{OA}=a_{5}+B_{5} \mathrm{O}_{3}$,

where the $a$ are intercepts and the $B$ and $\beta$ are regression slopes. In order to improve legibility MVK + MACR will be shortened to MVK when used as a subscript. Quadratic models with terms such as $\mathrm{CO}_{\mathrm{S}}$ times Bios were also considered, but did not yield insights or appreciable increases in performance.

For the standardized model, $\mathrm{M} 4_{\mathrm{S}}$, a comparison of $\beta_{4 \mathrm{CO}}$ with $\beta_{4 \mathrm{BIO}}$ gives the relative effect on $\mathrm{OA}_{\mathrm{S}}$ of changing $\mathrm{CO}_{\mathrm{S}}$ and Bios by the same multiple of their respective standard deviations. Standardization does not affect the value of $R^{2}$ nor does it change the signs of the coefficients of the explanatory variables. Standardized coefficients can be expressed in terms of bivariate Pearson correlation coefficients as

$$
\begin{aligned}
& \beta_{4 \mathrm{CO}}=\left(r_{\mathrm{OACO}}-r_{\mathrm{OABIO}} \times r_{\mathrm{COBIO}}\right) /\left(1-R_{\mathrm{COBIO}}^{2}\right), \\
& \beta_{4 \mathrm{BIO}}=\left(r_{\mathrm{OABIO}}-r_{\mathrm{OACO}} \times r_{\mathrm{COBIO}}\right) /\left(1-R_{\mathrm{COBIO}}^{2}\right),
\end{aligned}
$$

where, e.g., $r_{\mathrm{CO}} \mathrm{BIO}$ is the correlation coefficient between $\mathrm{CO}$ and Bio from M3. $\beta_{4 \mathrm{CO}}$ and $\beta_{4 \mathrm{BIO}}$ reduce to $r_{\mathrm{OACO}}$ and $r_{\mathrm{OABIO}}$, respectively, in the case that $\mathrm{CO}$ and $\mathrm{Bio}$ are uncorrelated.

In a three variable system spurious correlations arise because two variables that are correlated with a third are necessarily correlated with each other (Panofsky and Brier, 1968). For example, in the system OA, CO, Bio there is a spurious correlation between $\mathrm{OA}$ and $\mathrm{CO}$ due to both variables being correlated with Bio, given by $r_{\mathrm{OA} \mathrm{BIO}} \times r_{\mathrm{COBIO}}$. Likewise, there is a spurious correlation between OA and Bio due to both variables being correlated with $\mathrm{CO}$, given by $r_{\mathrm{OACO}} \times r_{\mathrm{CO}}$ BIO. Numerators of Eq. (1a) and (1b) are therefore bivariate correlations of OA with $\mathrm{CO}$ and Bio, respectively, in excess of the corresponding spurious value. Because $\mathrm{CO}$ and Bio can be highly correlated, both spurious correlations, can be large. For some transects, the linear models M1 and M2 predict a strong correlation between variables, while the $\beta$ s in model $\mathrm{M} 4_{\mathrm{s}}$ are of opposite sign. Thus, in some cases, the linear models can indicate that an explana-
Table 4. Plume perturbations, $\Delta s$, averaged over transects at five locations.

\begin{tabular}{lrrrrrr}
\hline \multirow{2}{*}{ Transect } & \multicolumn{6}{c}{$\Delta^{*}$} \\
\cline { 2 - 7 } & \multicolumn{7}{c}{$\begin{array}{r}\text { MVK } \\
\text { OA }\end{array}$} & CO & Isoprene & MACR & $\mathrm{CH}_{3} \mathrm{OH}$ & $\mathrm{O}_{3}$ \\
\hline Upwind & 3.0 & 23 & 0.32 & 0.26 & 3.1 & 13 \\
T0 & 3.2 & 42 & 0.38 & 0.38 & 1.9 & 12 \\
City-edge & 3.7 & 39 & 0.55 & 0.51 & 1.2 & 15 \\
T1 & 3.9 & 31 & 2.0 & 1.2 & 2.2 & 15 \\
Foothills & 1.3 & 13 & 1.0 & 0.75 & 1.3 & 6.4 \\
\hline
\end{tabular}

$* \Delta$ is the 90th percentile-10th percentile. Units are ppbv, except for organic aerosol (OA), which is $\mu \mathrm{g} \mathrm{m}^{-3}$.

tory variable promotes $\mathrm{OA}$, while in the context of M4 or $\mathrm{M} 4_{\mathrm{S}}$, the opposite is true.

A two variable model (e.g. M4) is judged to be an improvement over a single variable model (M1 or M2) according to whether the added variable produces a statistically significant increase in $R^{2}$. Even if the added variable is random, $R^{2}$ will increase as long as the added variable is not a linear function of the explanatory variables already in use. The relation between linear and bilinear values of $R^{2}$ can be found in Panofsky and Brier (1986, p. 112) and other statistics text books. Statistical significance is discussed in the Supplement where it is pointed out that because plumes are correlated structures with fewer degrees of freedom than data points, the usual ways of determining statistical significance, such as $t$ or $f$ tests, do not apply (Thiébaux and Zwiers, 1984; Trenberth, 1984).

\section{Results}

Tables 3 and 4 summarize chemical measurements from the G-1, providing backgrounds and plume perturbations for $\mathrm{OA}$, $\mathrm{CO}$, isoprene, $\mathrm{MVK}+\mathrm{MACR}, \mathrm{CH}_{3} \mathrm{OH}$, and $\mathrm{O}_{3}$ averaged over transects according to location. Background concentrations of the long-lived constituents, $\mathrm{OA}, \mathrm{CO}$, and $\mathrm{CH}_{3} \mathrm{OH}$ are to the first order about the same on all five legs. The short-lived species, isoprene and MVK + MACR, increase by approximately an order of magnitude from east to west, following changes in emissions. Ozone is an intermediate case. Calling the 10th percentile of concentration "background" comes closest to matching the traditional definition for species with long atmospheric residence time. Even so, backgrounds for $\mathrm{OA}, \mathrm{CO}$, and $\mathrm{CH}_{3} \mathrm{OH}$ have significant variability, which we will take advantage of for source attribution of OA.

From T0 eastward, $\triangle \mathrm{CO}$ is elevated relative to Upwind values. Biogenic mixing ratios have their major increase east of the City-Edge transect. Effects of dilution are apparent in the decrease of $\triangle \mathrm{CO}$ and $\triangle \mathrm{OA}$ at the Foothills transect, albeit based on only five transects from three flights. 


\subsection{Correlations for the spatial variability within individual transects}

Figure 2 shows values of $R^{2}$ obtained from models M1-M4. Regressions are done for each transect, then $R^{2}$ is averaged over transects at each location. Results are presented in three panels corresponding to the biogenic tracer used; isoprene, $\mathrm{MVK}+\mathrm{MACR}$, or $\mathrm{CH}_{3} \mathrm{OH}$. Each panel has a common blue trace representing $R^{2}$ from model M1, OA vs. CO. Adding a biogenic tracer to M1 gives the bilinear model, M4, with an $R^{2}$ shown by the black trace. The additional variance in OA explained by M4 as compared to M1, is in general small, showing that over the distance of an individual transect, OA mainly follows CO. Correlations of OA with isoprene are particularly low. Although the correlation of OA with MVK + MACR or $\mathrm{CH}_{3} \mathrm{OH}$ can be high (e.g., average $R^{2}$ of 0.39 and 0.47 , respectively, at T1), there is little to be gained, for most combinations of biogenic tracer and transect location, by adding either compound to $\mathrm{CO}$ because the $\mathrm{OA}-$ biogenic correlation is largely spurious. However, within the averages shown in Fig. 2, there is considerable variability and a minority of transects in which most of the explainable OA variance is due to a biogenic compound. Figures $\mathrm{S} 1-\mathrm{S} 3$ in the Supplement provide $R^{2}$ from models M1-M4 for all individual transects.

At this point the discussion shifts to the Sacramento plume proper, which consists of 56 transects on legs T0, City-Edge, T1, and Foothills. Coefficients of determination are shown for T1 transects in Fig. 3 (and repeated as part of Figs. S1S3). In most cases, especially ones in which a high fraction of the OA spatial variability can be explained, more of the $\mathrm{OA}$ variance is explained by $\mathrm{CO}$ than by a biogenic tracer. According to the average values of $R^{2}$ given in Table 5, adding the explanatory variable isoprene, MVK + MACR, or $\mathrm{CH}_{3} \mathrm{OH}$ to $\mathrm{M} 1$, causes $R^{2}$ to increase by 4,7 , or $13 \%$, respectively. Standardized regression coefficients in Table 5 confirm the importance of $\mathrm{CO}$ and show that of the three biogenic tracers, $\mathrm{OA}$ is best described by $\mathrm{CH}_{3} \mathrm{OH}$.

Examples of time series for CO, MVK + MACR, and OA for three plumes are given in Figs. 4 to 6 . Coefficients of determination for models M1-M4 and standardized regression slopes for models $\mathrm{M} 4_{\mathrm{S}}$ are provided in Table 6. In the first two plumes from flight 608b (Figs. 4 and 5) OA is well correlated with both CO and MVK + MACR and the two explanatory variables are themselves highly correlated. Small differences determine whether OA either follows CO or MVK + MACR more in the bilinear model, M4. In the third case from flight $628 \mathrm{~b}$ (Fig. 6), OA is almost perfectly correlated with $\mathrm{CO}$ and there is an absence of correlation with MVK + MACR. Transects were not long enough to fully observe both sides of a plume. Coverage was, however, usually more complete than the examples in Figs. 4 to 6.
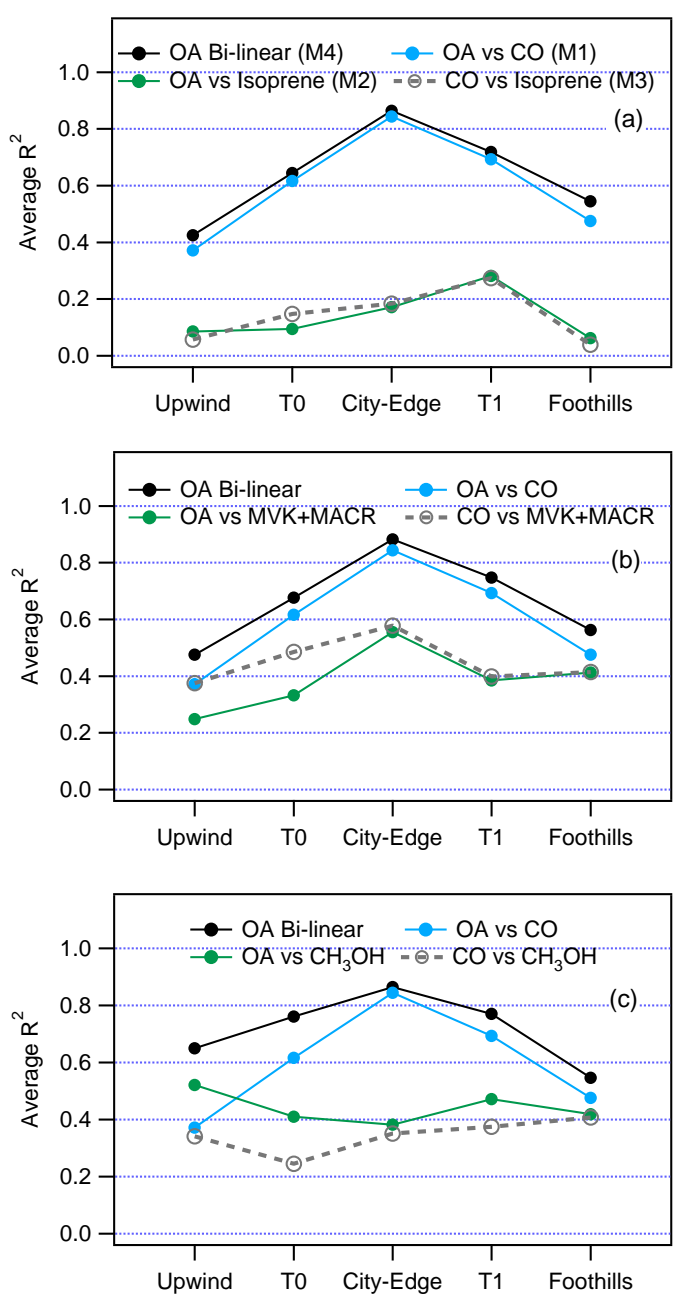

Figure 2. Average coefficient of determination $\left(R^{2}\right)$ for bilinear or linear least-squares regressions using data from five locations for plume transects shown in Fig. 1. Explanatory variables are (a) $\mathrm{CO}$ and isoprene, (b) $\mathrm{CO}$ and $\mathrm{MVK}+\mathrm{MACR}$, and (c) $\mathrm{CO}$ and $\mathrm{CH}_{3} \mathrm{OH}$. Panel (a) gives regression model in parenthesis.

\subsection{Regression analysis of plume perturbations}

Correlations have also been calculated amongst plume perturbation concentrations, defined for each transect as the 90th percentile minus the 10th percentile, and denoted here by the symbol $\Delta$. While correlations on individual transects are only sensitive to cross-plume spatial variations, the correlations between $\Delta$ quantities test how well plume perturbations in OA follow perturbations in CO, MVK + MACR, isoprene, $\mathrm{CH}_{3} \mathrm{OH}$, and $\mathrm{O}_{3}$, as these compounds vary in concentration according to position (i.e., T0 to Foothills) and according to day-to-day variations in meteorological conditions. Table 7 summarizes values of $R^{2}$ for linear regressions of all pairings of $\triangle \mathrm{OA}, \Delta \mathrm{CO}, \Delta \mathrm{MVK}+\mathrm{MACR}, \Delta$ Isoprene, $\Delta \mathrm{CH}_{3} \mathrm{OH}$, and $\Delta \mathrm{O}_{3}$. Also included are regression slopes and $R^{2}$ for the standardized bilinear models. Adding the explanatory vari- 

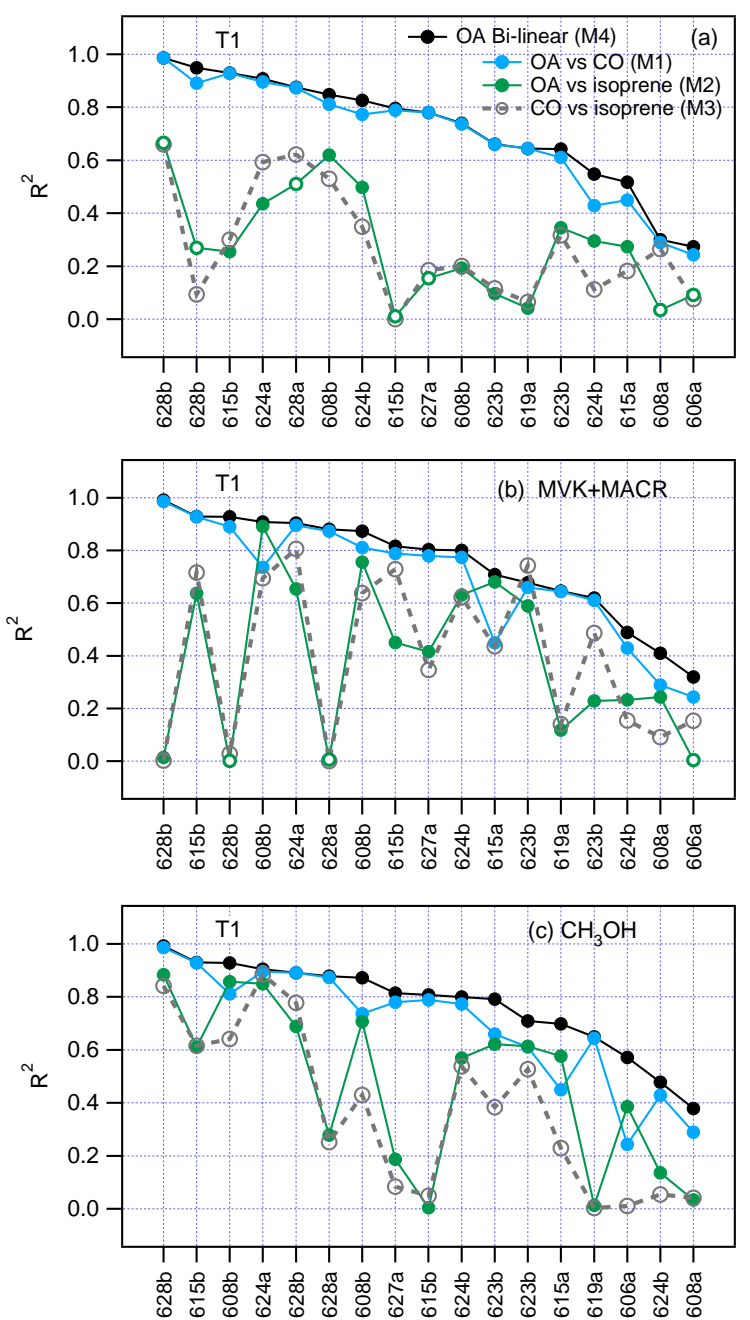

Figure 3. Coefficient of determination $\left(R^{2}\right)$ for transects on Leg T1, using $\mathrm{CO}$ as an anthropogenic tracer and (a) isoprene, (b) $\mathrm{MVK}+\mathrm{MACR}$, and (c) $\mathrm{CH}_{3} \mathrm{OH}$ as a biogenic tracer. Results rank ordered according to $R^{2}$ of bilinear model, M4-Bio. Open green circles indicates transects in which OA is anti-correlated with Bio. Legend in panel (a) identifies regression models.

able $\Delta$ isoprene, $\triangle \mathrm{MVK}+\mathrm{MACR}$, or $\Delta \mathrm{CH}_{3} \mathrm{OH}$ to $\triangle \mathrm{OA}$ vs. $\Delta \mathrm{CO}$ increases the explained variance from 69 to 76,72 or $76 \%$, respectively. For independent transects, increases in $R^{2}$ are significant with a $p$ value of 0.02 or better.

The inter-plume correlation analysis was repeated using background (10th percentile) values in place of $\Delta \mathrm{s}$. Figure 7 shows scatter plots for background OA vs. background $\mathrm{CO}, \mathrm{MVK}+\mathrm{MACR}$, isoprene, and $\mathrm{O}_{3}$, paired with the corresponding scatter plots for $\Delta$ variables. Plots of $\Delta$ variables correspond to the first column of data in Table 7 . Color coding identifies points according to transect location. Background OA is poorly correlated with other background species, with the exception of $\mathrm{OA}$ vs. $\mathrm{CH}_{3} \mathrm{OH}\left(R^{2}=0.82\right)$. In that case there is a similar relation and goodness of fit for transects at all locations. The poor correlation between back-
Table 5. Coefficients of determination for models M1-M5, where Bio is isoprene, MVK + MACR, or $\mathrm{CH}_{3} \mathrm{OH}$, applied to withintransect data. Average determined for 56 transects.

\begin{tabular}{|c|c|c|c|}
\hline \multirow[t]{2}{*}{ Model $^{\mathrm{a}}$} & \multicolumn{2}{|r|}{ Variables } & \multirow[t]{2}{*}{ average $R^{2}$} \\
\hline & $Y$ & $X(\mathrm{~s})$ & \\
\hline M1 & $\mathrm{OA}$ & $\mathrm{CO}$ & 0.68 \\
\hline M2-isoprene & $\mathrm{OA}$ & isoprene & 0.16 \\
\hline M3-isoprene & $\mathrm{CO}$ & isoprene & 0.18 \\
\hline M4-isoprene ${ }^{\mathrm{b}}$ & $\mathrm{OA}$ & $\mathrm{CO}$, isoprene & 0.71 \\
\hline M2-MVK + MACR & $\mathrm{OA}$ & MVK + MACR & 0.40 \\
\hline M3-MVK + MACR & $\mathrm{CO}$ & MVK + MACR & 0.47 \\
\hline $\mathrm{M} 4-\mathrm{MVK}+\mathrm{MACR}^{\mathrm{c}}$ & $\mathrm{OA}$ & $\mathrm{CO}, \mathrm{MVK}+\mathrm{MACR}$ & 0.73 \\
\hline $\mathrm{M} 2-\mathrm{CH}_{3} \mathrm{OH}$ & $\mathrm{OA}$ & $\mathrm{CH}_{3} \mathrm{OH}$ & 0.42 \\
\hline $\mathrm{M} 3-\mathrm{CH}_{3} \mathrm{OH}$ & $\mathrm{CO}$ & $\mathrm{CH}_{3} \mathrm{OH}$ & 0.32 \\
\hline $\mathrm{M} 4-\mathrm{CH}_{3} \mathrm{OH}^{\mathrm{d}}$ & $\mathrm{OA}$ & $\mathrm{CO}, \mathrm{CH}_{3} \mathrm{OH}$ & 0.77 \\
\hline M5 & $\mathrm{OA}$ & $\mathrm{O}_{3}$ & 0.57 \\
\hline
\end{tabular}

${ }^{a}$ Within a set of regressions, M1 to M4, missing values of either OA, CO, or biogenic tracer were treated by removing all three data (listwise deletion). ${ }^{\mathrm{b}}$ Average of standardized regression slopes for model M4-isoprene ${ }_{S}, \beta_{4 \mathrm{CO}}=0.80$, $\beta_{4}$ ISOPRENE $=-0.01$. $^{\mathrm{c}}$ Average of standardized regression slopes for model $\mathrm{M} 4-\mathrm{MVK}+\mathrm{MACR}_{\mathrm{S}}, \beta_{4 \mathrm{CO}}=0.74, \beta_{4} \mathrm{MVK}=0.06 .{ }^{\mathrm{d}}$ Average of standardized regression slopes for model $\mathrm{M} 4-\mathrm{CH}_{3} \mathrm{OH}_{\mathrm{S}}, \beta_{4 \mathrm{CO}}=0.67, \beta_{4} \mathrm{CH}_{3} \mathrm{OH}=0.29$.

ground $\mathrm{OA}$ and $\mathrm{CO}$ is surprising in view of model results that show the Bay Area to be an important source region (Fast et al., 2012). Amongst the $\Delta$ variables, $\Delta \mathrm{OA}$ has the highest correlation with $\Delta \mathrm{O}_{3}\left(R^{2}=0.88\right)$. Similar to the withintransect spatial correlations, the variance of OA is better described by the anthropogenic tracer, $\mathrm{CO}\left(R^{2}=0.69\right)$, than by a biogenic tracer.

\subsection{Comparisons of low- and high-concentration transects}

A third way of looking at $\mathrm{OA}$ as a function of anthropogenic and biogenic tracers is to divide the 56 transects into subsets according to tracer mixing ratio (Setyan et al., 2012; Shilling et al., 2013). Following Shilling et al. (2013), we have parsed our data into subsets according to whether mixing ratios of anthropogenic and biogenic tracers are low or high, defined here as being in the bottom or top third of their ranked distribution. Average concentrations of $\triangle \mathrm{OA}$ were determined for the four combinations of low and high $\triangle \mathrm{CO}$ and $\triangle \mathrm{Bio}$, with Bio being isoprene, MVK + MACR, or $\mathrm{CH}_{3} \mathrm{OH}$.

Average concentrations for the $\triangle \mathrm{OA}, \triangle \mathrm{CO}, \Delta \mathrm{Bio}$ systems are shown in Figs. 8-10. In the case of MVK + MACR, the nine samples that simultaneously have a high mixing ratio of $\triangle \mathrm{CO}$ and $\triangle \mathrm{MVK}+\mathrm{MACR}$ (high-high subset) have an average $\Delta \mathrm{OA}=8.6 \mu \mathrm{g} \mathrm{m}^{-3}$ (Fig. 9). In contrast, subsets having a low mixing ratio of either $\triangle \mathrm{CO}$ and $\triangle \mathrm{MVK}+\mathrm{MACR}$ or both have a low average $\Delta \mathrm{OA}\left(1.1\right.$ to $\left.2.4 \mu \mathrm{g} \mathrm{m}^{-3}\right)$. Data subsets defined with $\Delta$ isoprene or $\Delta \mathrm{CH}_{3} \mathrm{OH}$ share the property that only the high anthropogenic, high biogenic subset has a high average $\triangle \mathrm{OA}$. However, it can be seen from 
Table 6. Coefficients of determination for models M1-M4 and standardized regression slopes for model M4 $4_{S}$ for three transects.

\begin{tabular}{|c|c|c|c|c|c|}
\hline \multirow[t]{2}{*}{ Model } & \multicolumn{2}{|r|}{ Variables } & \multirow{2}{*}{$\begin{array}{r}608 b^{*} \\
\text { City-edge }\end{array}$} & \multirow{2}{*}{$\begin{array}{r}608 b^{*} \\
\mathrm{~T} 1\end{array}$} & \multirow{2}{*}{$\begin{array}{r}628 b^{*} \\
\text { T1 }\end{array}$} \\
\hline & $Y$ & $X(\mathrm{~s})$ & & & \\
\hline $\mathrm{M} 1, R^{2}$ & $\mathrm{OA}$ & $\mathrm{CO}$ & 0.94 & 0.74 & 0.99 \\
\hline $\mathrm{M} 2, R^{2}$ & OA & MVK + MACR & 0.89 & 0.89 & 0.01 \\
\hline $\mathrm{M} 3, R^{2}$ & $\mathrm{CO}$ & MVK + MACR & 0.89 & 0.69 & 0.00 \\
\hline $\mathrm{M} 4, R^{2}$ & $\mathrm{OA}$ & $\mathrm{CO}, \mathrm{MVK}+\mathrm{MACR}$ & 0.95 & 0.91 & 0.99 \\
\hline $\mathrm{M}_{4}, \beta_{4 \mathrm{CO}}$ & $\mathrm{OA}_{\mathrm{S}}$ & $\mathrm{CO}_{\mathrm{S}}, \mathrm{MVK}+\mathrm{MACR}_{\mathrm{S}}$ & 0.70 & 0.24 & 0.99 \\
\hline $\mathrm{M}_{\mathrm{S}}, \beta_{4 \mathrm{MVK}}$ & $\mathrm{OA}_{\mathrm{S}}$ & $\mathrm{CO}_{\mathrm{S}}, \mathrm{MVK}+\mathrm{MACR}_{\mathrm{S}}$ & 0.29 & 0.75 & 0.07 \\
\hline
\end{tabular}

* See Figs. 4-6.
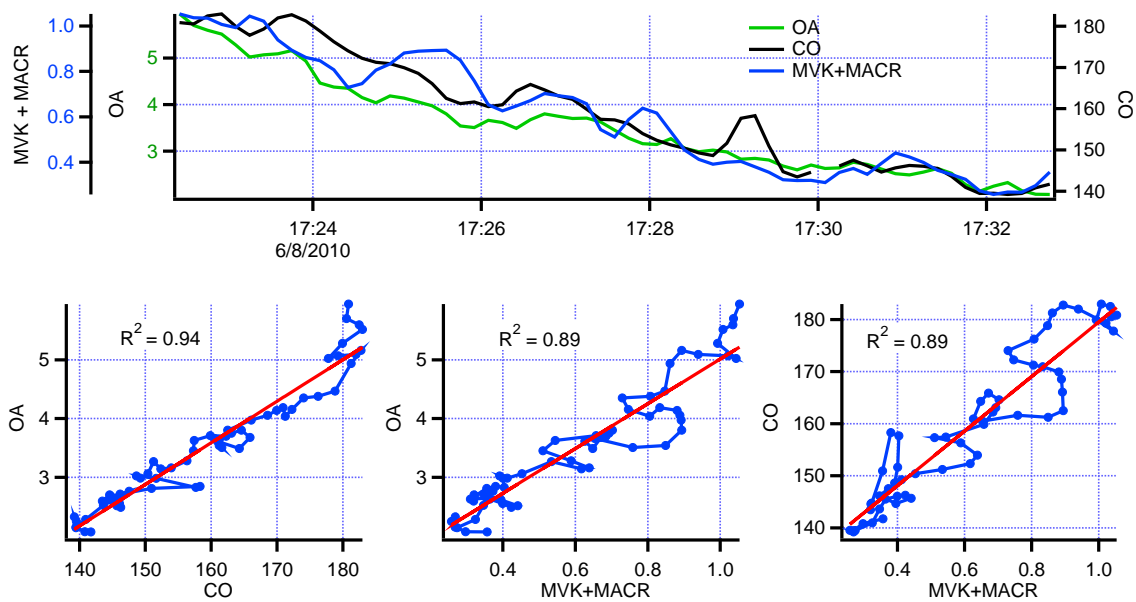

Figure 4. Flight 608b City-Edge transect. Top graph: time series of OA, CO, and MVK + MACR. OA in $\mu g \mathrm{~m}^{-3}$; CO and MVK + MACR in ppbv. Time is Pacific Standard Time. Bottom plots: correspond from left to right to models M1, M2, and M3 listwise deletion used for correlations but not used for graphs. Data points on scatter plots connected to give a sense of time continuity. Red lines are least-squares fit to data.

Figs. $8-10$ that a component of the elevated $\triangle \mathrm{OA}$ in the high-high subset might be due to the subset having an elevated mixing ratio of anthropogenic and/or biogenic precursors (i.e., the high-high subset has more CO than the lowBio-high-CO subset and more Bio than the low-CO-highBio subset). If $\mathrm{A}-\mathrm{B}$ interactions did not exist, then by definition $\triangle \mathrm{OA}$ would respond independently to changes in anthropogenic and biogenic precursors. We assume that the response would be linear. For each choice of $\Delta B$ Bio, a bilinear model (M4) was applied to a set of transects that did not include those in the high-high subset. The resulting intercept and slopes were used to calculate $\triangle \mathrm{OA}$ for all transects. Observed and calculated values of $\triangle \mathrm{OA}$ are shown in Fig. 11. In this approach, an A-B synergism should show up as a model under-prediction for the high-high subset. Indeed, there is an under-prediction of $\triangle \mathrm{OA}$ in the high-high subset but it is smaller than suggested by comparing $\triangle \mathrm{OA}$ amongst subsets in Figs. 8-10. The ratio, $\Delta \mathrm{OA}$ (observed) / $\Delta \mathrm{OA}$ (bilinear model) for the high-high subset is $1.2(0.3), 1.5(0.3)$, and 1.2 (0.3), for isoprene, $\mathrm{MVK}+\mathrm{MACR}$, and $\mathrm{CH}_{3} \mathrm{OH}$, respec- tively. Numbers in parentheses are normalized root mean square deviations, a measure of the spread in A-B enhancements extracted from the high-high subset points in Fig. 11. Using only the averaged parsed data in Figs. 8-10 to remove precursor effects (see Fig. 8 caption) yields an A-B interaction factor of 1.5, 3.6, and 1.3 for isoprene, MVK + MACR, and $\mathrm{CH}_{3} \mathrm{OH}$, respectively, closer to the results of Setyan et al. (2012) and Shilling et al. (2013). Note that the choice of data subset used for the low concentration bilinear fit will effect the calculated enhancements and may contribute to differences between values determined here and published values.

\section{Discussion}

Three analysis methods were used. In method 1 , spatial variations in OA are compared with spatial variations of $\mathrm{CO}$ and Bio on a single transect. Our metric for a successful explanatory variable is that it accounts for a high fraction of variance in $\mathrm{OA}$ and that the standardized regression slopes, i.e. 

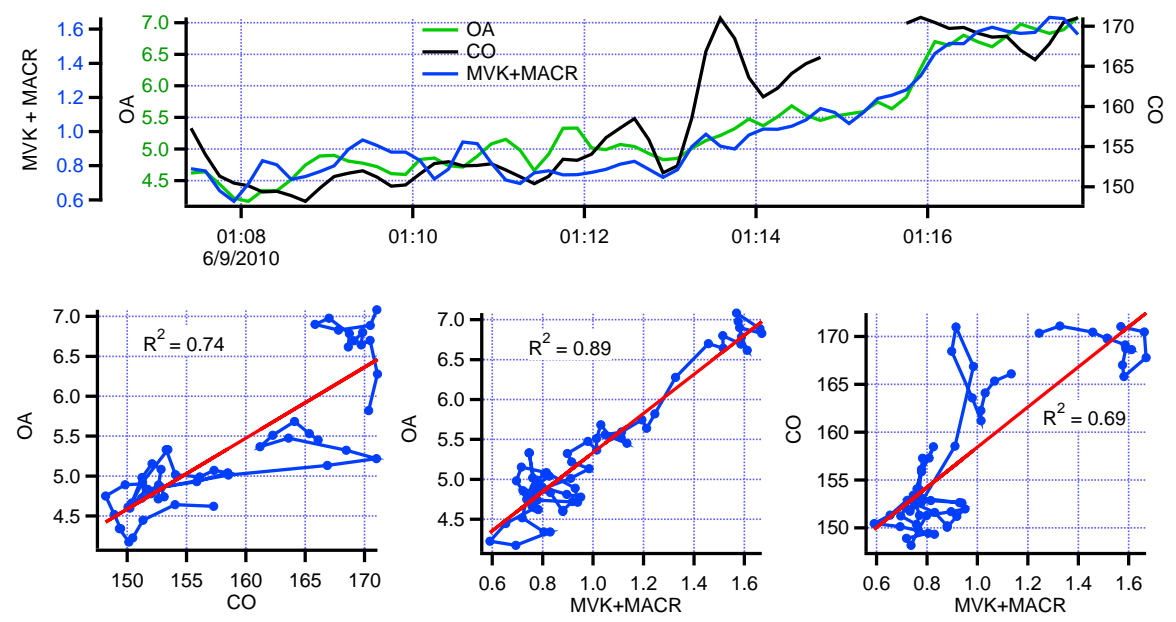

Figure 5. Flight 608b T1 transect. Same format as Fig. 4.
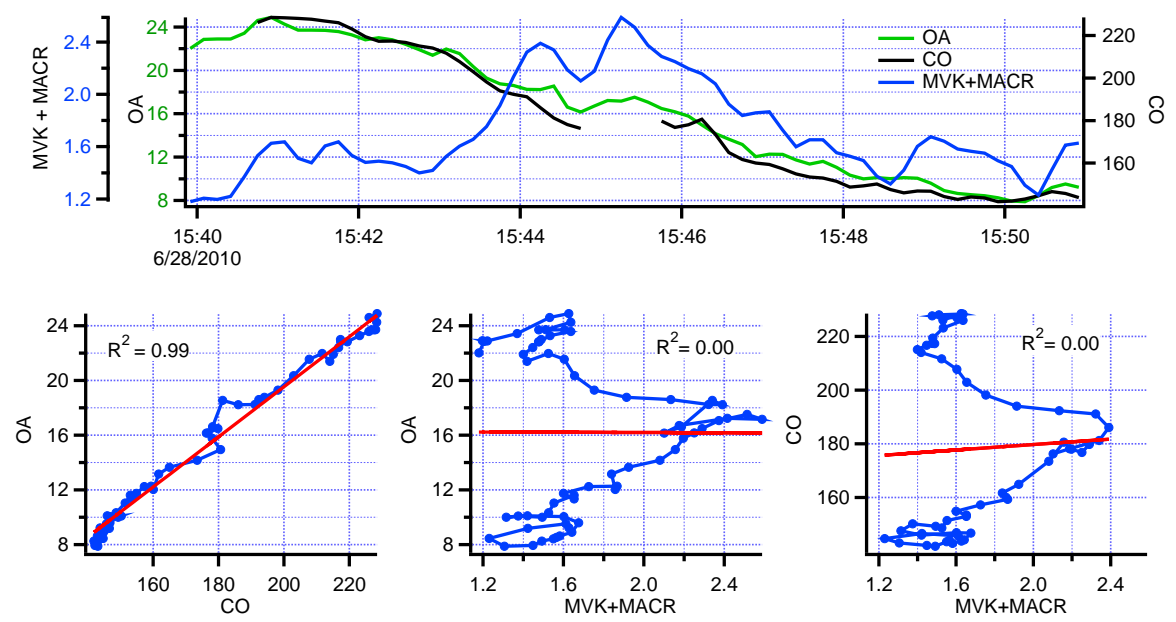

Figure 6. Flight 628b T1 transect. Same format as Fig. 4.

$\beta \mathrm{s}$ in model $\mathrm{M} 4_{\mathrm{S}}$, indicate that the explained variance is not spurious. By these criteria the average dependence of OA on $\mathrm{CO}$ is greater than its dependence on the biogenic tracer $\mathrm{CH}_{3} \mathrm{OH}$, and much greater than its dependence on isoprene or MVK + MACR.

Although, on average, most of the explained variance in $\mathrm{OA}$ is due to $\mathrm{CO}$, there are transects in which $\mathrm{OA}$ is highly correlated with isoprene, $\mathrm{MVK}+\mathrm{MACR}$ or $\mathrm{CH}_{3} \mathrm{OH}$ (Figs. 3, S1-S3). Examples for MVK + MACR are the sequential-in-time City-Edge and T1 transects from the 608b flight shown in Figs. 4 and 5. Complicating the interpretation of method 1 in general and the 608a transects in particular, is the circumstance that the anthropogenic and biogenic tracers, $\mathrm{CO}$ and MVK + MACR, are themselves often highly correlated. As can be seen by comparing the standardized coefficients in Table 6 with values of $R^{2}$ for models M1-M4, small difference in correlation coefficients can be associated with large changes in the relative importance of
$\mathrm{CO}$ and MVK + MACR as judged by the standardized regression slopes. By most measures an $R^{2}$ of 0.89 for OA vs. MVK + MACR on the 608b City-Edge transect would be considered excellent. But, because of the slightly higher $R^{2}$ for OA vs. $\mathrm{CO}(0.94)$ and the high correlation between $\mathrm{CO}$ and MVK + MACR (0.89), a bilinear model assigns most of the variance in $\mathrm{OA}$ to $\mathrm{CO}$. An opposite conclusion is reached for the $608 \mathrm{~b}, \mathrm{~T} 1$ transect.

The spatial correlation between $\mathrm{CO}$ and, for example, MVK + MACR on individual transects is highly variable (Figs. 3b and S2). On average it is somewhat greater than the correlation between OA and MVK + MACR. It is not clear what processes cause a sometimes high but variable correlation between anthropogenic and biogenic VOCs. A possible explanation is that it is an accident of geography whereby under certain wind directions the plumes from urban and forested areas line up, while under other wind directions the overlap is lessened or eliminated. Faster oxida- 
Table 7. Coefficients of determination between plume $\Delta^{\mathrm{a}}$ values for $\mathrm{OA}, \mathrm{CO}$, isoprene, $\mathrm{MVK}+\mathrm{MACR}, \mathrm{CH}_{3} \mathrm{OH}$, and $\mathrm{O}_{3}$ based on data set of 56 transects.

\begin{tabular}{|c|c|c|c|c|c|c|}
\hline \multirow[t]{2}{*}{ Dependent variable } & \multicolumn{6}{|c|}{ Explanatory variable ${ }^{\mathrm{a}}$} \\
\hline & $\triangle \mathrm{OA}$ & $\Delta \mathrm{CO}$ & $\Delta$ Isoprene & $\triangle \mathrm{MVK}+\mathrm{MACR}$ & $\Delta \mathrm{CH}_{3} \mathrm{OH}$ & $\Delta \mathrm{O}_{3}$ \\
\hline$\Delta \mathrm{OA}^{\mathrm{b}}$ & 1 & & & & & \\
\hline$\Delta \mathrm{CO}$ & 0.69 & 1 & & & & \\
\hline$\Delta$ Isoprene & 0.11 & 0.01 & 1 & & & \\
\hline$\triangle \mathrm{MVK}+\mathrm{MACR}$ & 0.15 & 0.06 & 0.57 & 1 & & \\
\hline$\Delta \mathrm{CH}_{3} \mathrm{OH}$ & 0.55 & 0.43 & 0.13 & 0.25 & 1 & \\
\hline$\Delta \mathrm{O}_{3}$ & 0.88 & 0.61 & 0.08 & 0.08 & 0.35 & 1 \\
\hline $\begin{array}{l}\Delta \text { defined for each transect } \\
\text { variables: } \\
\Delta \mathrm{OA}_{\mathrm{S}}=\beta_{4 \Delta \mathrm{CO}} \Delta \mathrm{CO}_{\mathrm{S}}+\beta \\
\Delta \mathrm{OA}_{\mathrm{S}}=\beta_{4} \Delta \mathrm{CO} \Delta \mathrm{CO}_{\mathrm{S}}+\beta \\
\Delta \mathrm{OA}_{\mathrm{S}}=\beta_{4} \Delta \mathrm{CO} \Delta \mathrm{CO}_{\mathrm{S}}+\beta\end{array}$ & $\begin{array}{l}\text { the } 90 \text { th } \\
\text { OPRENI } \\
\mathrm{MVK} \Delta \mathrm{N} \\
\mathrm{CH}_{3} \mathrm{OH}\end{array}$ & $\begin{array}{l}\text { percentile } \\
\mathrm{J} \text { Isoprene } \\
\mathrm{JK}+\mathrm{MA} \\
\mathrm{CH}_{3} \mathrm{OH}_{\mathrm{S}}\end{array}$ & $\begin{array}{l}\beta_{4} \text { concentration- } \\
\beta_{4} \mathrm{CO}=0.8 \\
\mathrm{R}_{\mathrm{S}}: \beta_{4} \Delta \mathrm{CO}= \\
4 \Delta \mathrm{CO}=0.60,\end{array}$ & $\begin{array}{l}\text { th percentile. }{ }^{\mathrm{b}} \text { Bilinear } \\
{ }^{4} \Delta \mathrm{ISOPRENE}=0.26, R \\
8, \beta_{4} \Delta \mathrm{MVK}=0.19, R^{2} \\
\Delta \mathrm{CH}_{3} \mathrm{OH}=0.35, R^{2}=\end{array}$ & $\begin{array}{l}\text { gression with } \\
=0.76 \text {. } \\
.72 \text {. }\end{array}$ & ardized \\
\hline
\end{tabular}

tion of isoprene in the high $\mathrm{NO}_{x}$ anthropogenic Sacramento plume could be a contributing factor. Perhaps related is the observation by Dreyfus et al. (2002) of the co-advection of anthropogenic and biogenic compounds from the direction of Sacramento to the Blodgett Forest Research Station.

In Method 2, plume perturbations $(\Delta s)$ are defined on each downwind transect and for each species of interest. Correlation coefficients calculated amongst transects quantify the extent to which linear and bilinear combinations of $\Delta$ tracers $\left(\mathrm{CO}\right.$, isoprene, $\mathrm{MVK}+\mathrm{MACR}, \mathrm{CH}_{3} \mathrm{OH}$, and $\left.\mathrm{O}_{3}\right)$ can explain the variations of $\triangle \mathrm{OA}$ that occur as chemical and meteorological conditions vary from flight to flight and with transect location. As with method 1, we find that $\mathrm{CO}$ is more successful in explaining the variability of $\mathrm{OA}$, in comparison to biogenic tracers. This can be seen from the scatter diagrams in Fig. 7 and from the standardized coefficients for the bilinear model $\mathrm{M}_{\mathrm{S}}$ in Table 7 .

A notable feature of the correlations amongst transects is that $\Delta \mathrm{O}_{3}$ explains $88 \%$ of the variance in $\Delta \mathrm{OA}$. A display of Fig. $7 \mathrm{j}$ on a $\log -\log$ scale (not shown) indicates that the $\Delta \mathrm{OA}-\Delta \mathrm{O}_{3}$ relation stays approximately constant at low concentrations. Figure $7 \mathrm{j}$ also shows that the same relation holds at each of the four downwind transect locations. The high $\Delta \mathrm{OA}-\Delta \mathrm{O}_{3}$ correlation is evidence that most $\mathrm{OA}$ above background originates from secondary chemistry. This assignment is in agreement with findings from many locations that SOA is correlated with other oxidized species and in agreement with the analysis of CARES observations by Setyan et al. (2012) and Shilling et al. (2013). A mechanistic reason for a relation between $\mathrm{OA}$ and $\mathrm{O}_{3}$ was proposed by Herndon et al. (2008) based on a chemical mechanism in which $\mathrm{OH}+\mathrm{VOC}$ was the rate limiting step in $\mathrm{O}_{3}$ production, and also in forming low volatility VOC oxidation products that partition to the aerosol phase. The least-squares fit in Fig. $7 \mathrm{j}$ has a slope of $225 \mu \mathrm{g} \mathrm{m}^{-3}$ per ppm $\mathrm{O}_{3}$, as compared with the $104-180 \mu^{-3} \mathrm{~m}^{-3}$ per ppm O${ }_{3}$ slopes found by Herndon et al. (2008) in Mexico City outflow. Differences could reflect a $\pm 30 \%$ uncertainty in AMS measurements (Canagaratna et al., 2007) or variations in processing conditions.

Because of the mismatch in atmospheric lifetimes between isoprene or MVK+MACR and OA, it is not clear whether a correlation should be expected. Shilling et al. (2013) have made an argument based on changes between pseudo Lagrangian morning and afternoon measurements, that an anti-correlation is consistent with OA formation from biogenics that have been depleted by oxidation reactions. Robust relations between SOA and biogenic tracers are typically not found. For example, de Gouw et al. (2005) present aerosol and trace gas measurements from the Ronald H. Brown, taken off the coast of a region in Maine with high biogenic emission rates. Sub- $\mu \mathrm{m}$ OA was observed to be highly correlated with the anthropogenic tracer, iso-propyl nitrate, but not correlated with either monoterpenes or isoprene. A similar lack of correlation was found by Sullivan et al. (2006) and Weber et al. (2007). In contrast, Slowik et al. (2010) showed an $R^{2}$ of 0.71 for a regression of less oxygenated SOA (OOA-2; $\mathrm{O} / \mathrm{C}=0.46)$ vs. MVK + MACR, concluding on the basis of the MVK + MACR lifetime that OOA-2 was formed in the relatively recent past. Setyan et al. (2012) also observed a high correlation $\left(R^{2}=0.61\right)$ between MVK + MACR and a more-oxidized OOA $(\mathrm{O} / \mathrm{C}=0.54)$ at $\mathrm{T} 1$.

Unlike isoprene and MVK + MACR, the atmospheric lifetime of $\mathrm{CH}_{3} \mathrm{OH}$ is comparable to that of SOA. Standardized regression coefficients averaged over all transects (Table 5) indicate that $\mathrm{CH}_{3} \mathrm{OH}$ captures the spatial variance in OA better than short-lived biogenic tracers. The same is true for regressions amongst transects based on $\Delta$ values (Table 7). However, in methods 1 and 2, most of the variance in $\mathrm{OA}$ or $\triangle \mathrm{OA}$ is still captured by $\mathrm{CO}$. Correlations and standardized regression coefficients, for individual transects and amongst transects, are therefore consistent with an anthropogenic source for most of the OA formed downwind of Sacramento. 

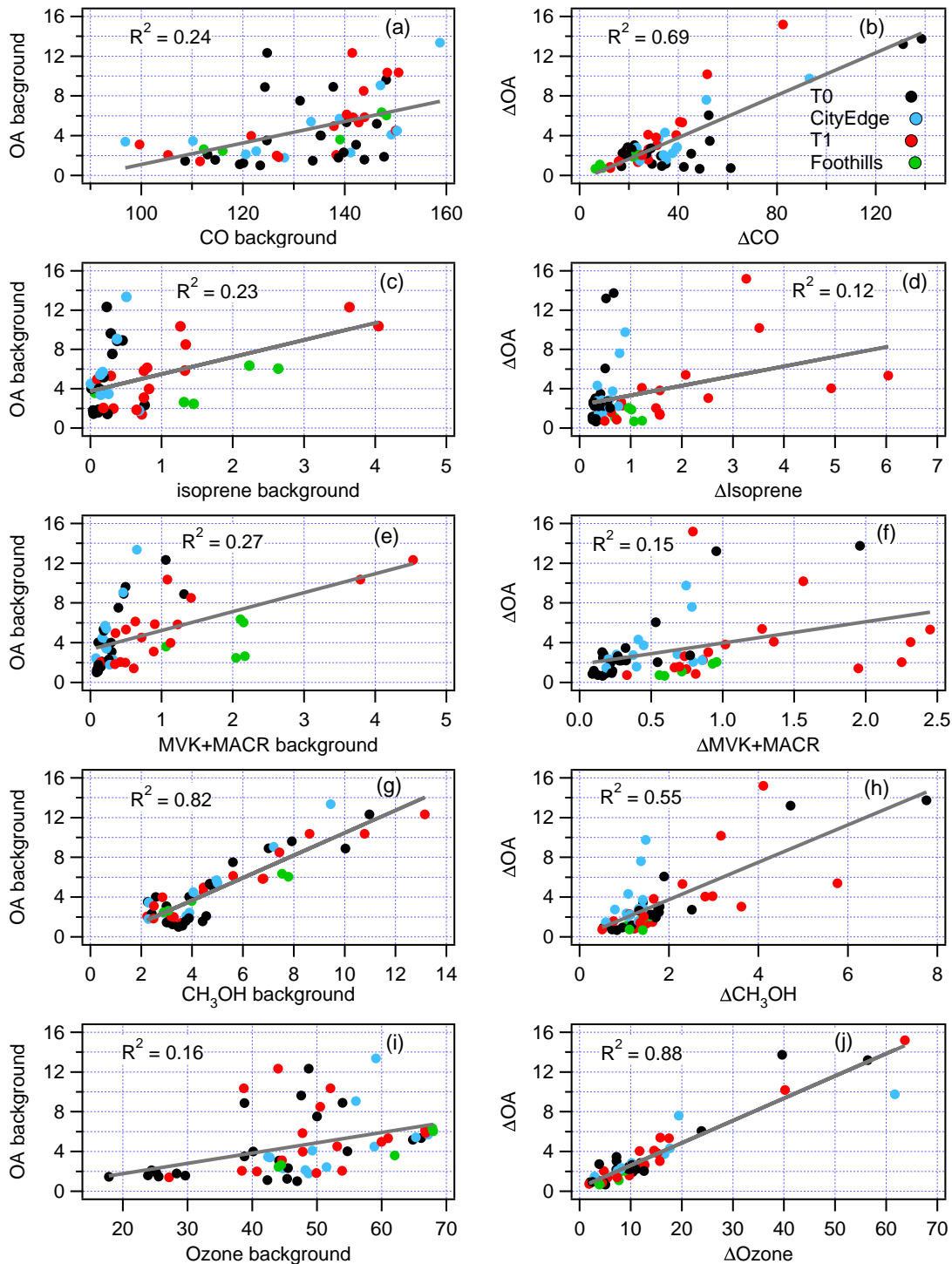

Figure 7. $\mathrm{OA}$ as a function of $\mathrm{CO}$, isoprene, $\mathrm{MVK}+\mathrm{MACR}, \mathrm{CH}_{3} \mathrm{OH}$, and $\mathrm{O}_{3}$ for 56 transects. Background concentrations in panels on left-hand side; $\Delta$ Concentrations on the right-hand side. Color legend in panel (b) identifies data according to location. Gray lines are linear least-squares fits with $R^{2}$ given in each panel.

Figure 7 shows that the variance in background $\mathrm{OA}$ is uniquely captured by background $\mathrm{CH}_{3} \mathrm{OH}$, with an explained variance of $82 \%$ compared to 23 to $27 \%$ for background $\mathrm{CO}$, isoprene, or MVK + MACR. The excellent fit between background $\mathrm{OA}$ and background $\mathrm{CH}_{3} \mathrm{OH}$ and the poor fit with $\mathrm{CO}$ is what would be expected if background SOA is primarily biogenic.

In method 3, concentrations in the form of $\Delta$ values are used to define plume-transect subsets, which have low or high mixing ratios of $\mathrm{CO}$ and either isoprene, $\mathrm{MVK}+\mathrm{MACR}$, or $\mathrm{CH}_{3} \mathrm{OH}$. Of the four combinations of low and high values of $\triangle \mathrm{CO}$ and $\triangle \mathrm{Bio}$, only the subset with a high mixing ratio of both anthropogenic and biogenic tracers has high average $\triangle \mathrm{OA}$. However, according to method 1 , most transects have a correlation between OA and biogenic tracers that is low and/or spurious, such that the addition of a biogenic to an OA vs. CO model, produces only a modest improvement in explaining the variance of OA during a plume transect. In method 2, there is a poor correlation between $\triangle \mathrm{OA}$ and $\triangle$ isoprene or $\triangle \mathrm{MVK}+\mathrm{MACR}$. The correlation between $\triangle \mathrm{OA}$ and $\Delta \mathrm{CH}_{3} \mathrm{OH}$ is somewhat higher but still lower than that between $\triangle \mathrm{OA}$ and $\triangle \mathrm{CO}$. We recognize the deficiencies in using short-lived biogenic tracers, yet in method 3 these same biogenic tracers as well as the long-lived $\mathrm{CH}_{3} \mathrm{OH}$ can split the data set into subsets with and without high $\triangle \mathrm{OA}$.

The association between simultaneous high mixing ratios of anthropogenic and biogenic tracers and high $\triangle \mathrm{OA}$ is heav- 


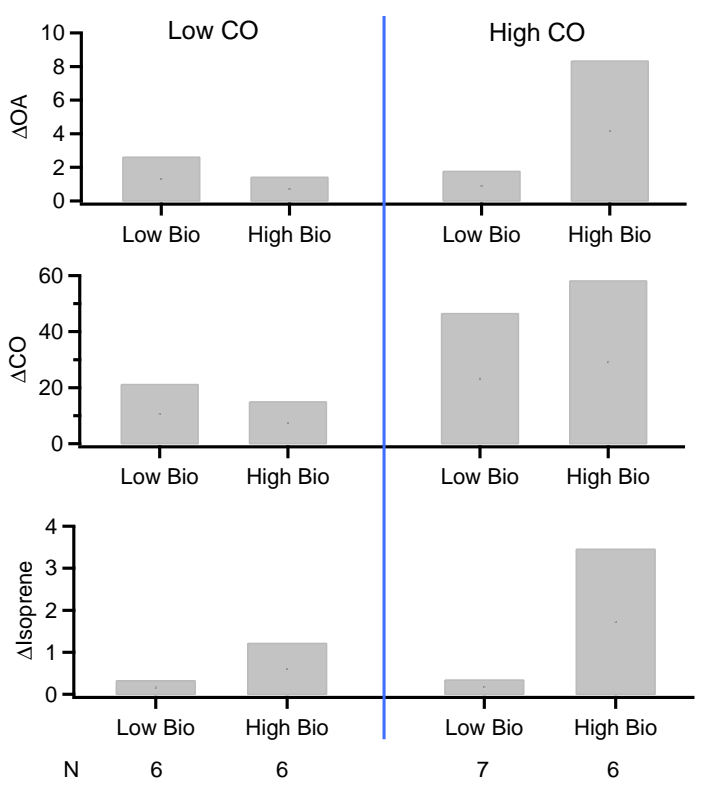

Figure 8. Values of $\Delta \mathrm{OA}, \Delta \mathrm{CO}$, and $\Delta \mathrm{Isoprene}$ for 4 subsets of transects. Pairs of bars labeled low $\mathrm{CO}$ and high $\mathrm{CO}$ have $\Delta \mathrm{CO}$ values that are below the $33 \mathrm{rd}$ percentile and above the 67 th percentile, respectively. Bars labeled low Bio and high Bio have $\Delta$ Isoprene values that are below the 33 rd percentile and above the 67 th percentile, respectively. Number of transects in each subset given at bottom. $\triangle \mathrm{CO}$ ratio and $\Delta \mathrm{Bio}$ ratio give effects of precursor mixing ratio on an $\mathrm{A}-\mathrm{B}$ interaction relative to the expectation that $\triangle \mathrm{OA}$ is a bilinear function of $\Delta \mathrm{CO}$, and $\triangle \mathrm{Bio}: \triangle \mathrm{CO}$ ratio is $(\triangle \mathrm{CO}$ : high $\mathrm{CO}$, high $\mathrm{Bio}) /(\Delta \mathrm{CO}$ : high $\mathrm{CO}$, low Bio). $\Delta \mathrm{Bio}$ ratio is $(\Delta \mathrm{Bio}$ : high $\mathrm{CO}$, high $\mathrm{Bio}) /(\Delta \mathrm{Bio}$ : high $\mathrm{CO}$, low Bio).

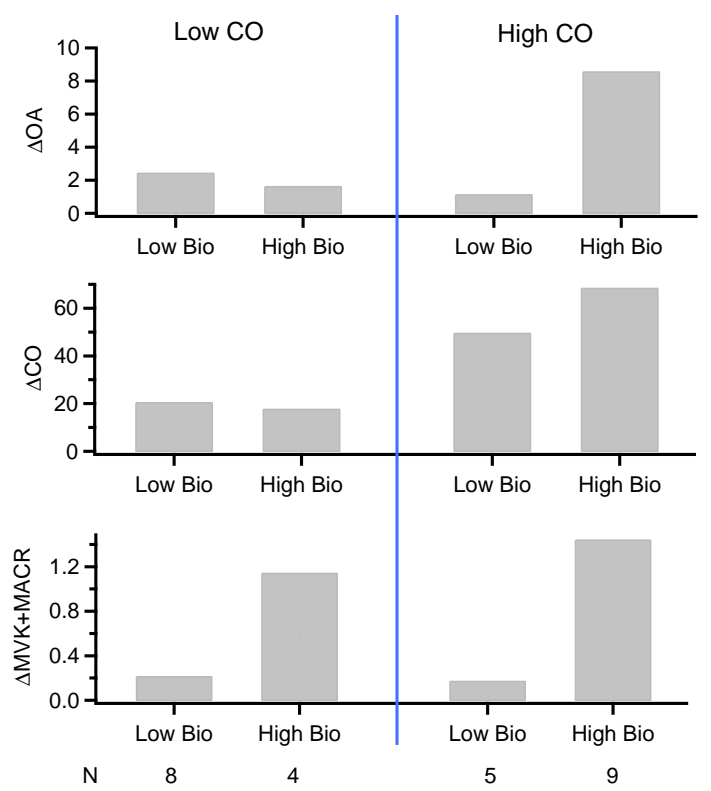

Figure 9. Bar graphs for subsets defined on the basis of $\Delta \mathrm{CO}$ and $\triangle \mathrm{MVK}+\mathrm{MACR}$. Same format as Fig. 8.

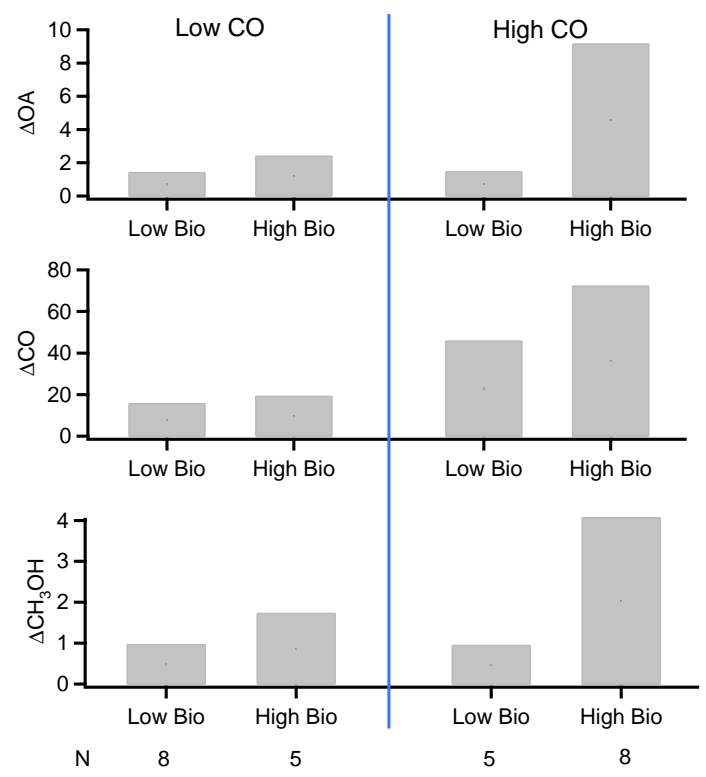

Figure 10. Bar graphs for subsets defined on the basis of $\triangle \mathrm{CO}$ and $\Delta \mathrm{CH}_{3} \mathrm{OH}$. Same format as Fig. 8 .

ily reliant on data from two flights on 28 June as this was the only day in which $\triangle \mathrm{OA}$ exceeded $6 \mu \mathrm{g} \mathrm{m}^{-3}$. What was distinctive about this day? According to Fast et al. (2012), from 22 June till the end of the field campaign on 28 June, winds at $700 \mathrm{hPa}$ were light and variable. After 25 June there was a steady increase in maximum day time temperature; 27 and 28 June had the warmest temperatures, approaching $40^{\circ} \mathrm{C}$ at T0 on the 28th. Ozone also reached its highest value of $90 \mathrm{ppb}$ at T0. Wind speeds at the G-1 altitude were $\sim 2 \mathrm{~m} \mathrm{~s}^{-1}$. A detailed description of chemical conditions on 28 June is given by Shilling et al. (2013). In brief, during these two flights isoprene reached $13 \mathrm{ppb}, \mathrm{O}_{3}$ approached $120 \mathrm{ppb}, \mathrm{CO}$ was in excess of $260 \mathrm{ppb}$, and OA more than $25 \mu \mathrm{g} \mathrm{m}^{-3}$. Except for $\mathrm{CO}$, these values are the highest observed from the G-1 during CARES.

The link between temperature and photochemistry is complex, involving changes in PAN lifetime, anthropogenic and biogenic emission rates, photolysis rates, and water vapor (Sillman and Samson, 1995). In addition, high temperatures are often accompanied by some measure of poor ventilation, promoting the buildup of primary pollutants such as observed on 28 June. Daily maximum ozone, obtained from monitoring networks, show a strong positive correlation with temperature at most locations, including Sacramento (Steiner et al., 2006, 2010). Over most of the temperature range of interest, emission rates for isoprene and terpenes increase exponentially with leaf temperature (Guenther et al., 1993), consistent with the temperature trend for daily maximum isoprene mixing ratio observed in Sacramento (Steiner et al., 2010) and at Blodgett Forrest (Dreyfus et al., 2002). All of the factors necessary to create simultaneous high concentrations of $\Delta \mathrm{OA}, \Delta \mathrm{CO}, \Delta$ isoprene, $\Delta \mathrm{CH}_{3} \mathrm{OH}$, and $\Delta \mathrm{O}_{3}$ are in place on 

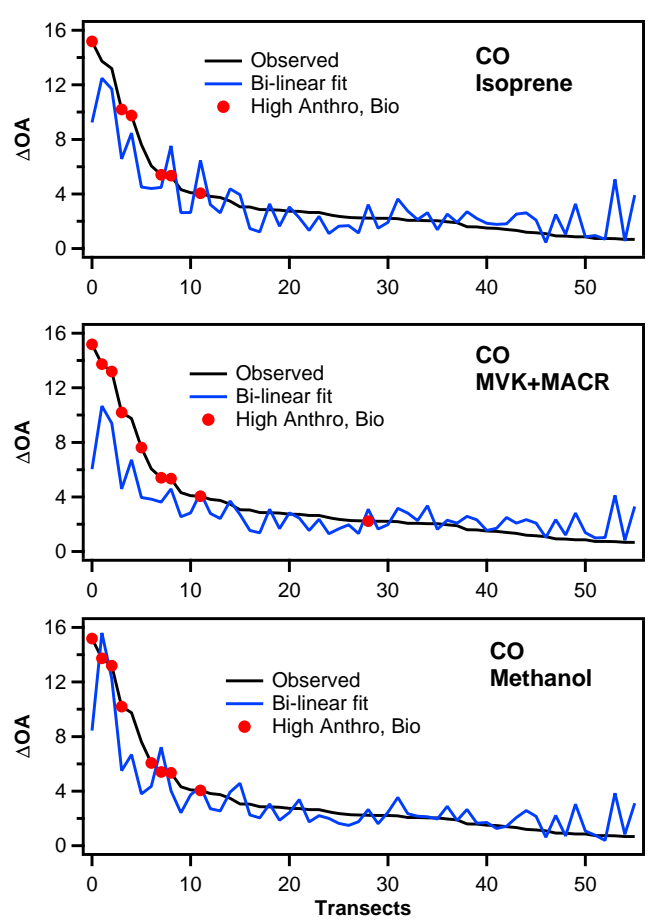

Figure 11. Observed $\triangle \mathrm{OA}$ presented in descending order. Blue trace is $\triangle \mathrm{OA}$ from bilinear model using $\triangle \mathrm{CO}$ and (a) Isoprene, (b) $\triangle \mathrm{MVK}+\mathrm{MACR}$, and (c) $\Delta \mathrm{CH}_{3} \mathrm{OH}$ as explanatory variables. Regressions did not use transects from the high $\Delta \mathrm{CO}$, high $\Delta \mathrm{Bio}$ subsets, indicated by red symbols.

28 June. The driving meteorological factors, however, do not necessarily affect OA and OA precursors equally, with the result that trends in the parsed data can exist without strong correlations between $\triangle \mathrm{OA}$ and $\Delta \mathrm{Bio}$.

According to our definition of plume perturbations $(\Delta s)$ approximately $60 \%$ of peak OA in the Sacramento plume is background. This value is determined by a 56 transect average of the ratio OA(10th percentile) / OA (90th percentile). A high contribution from background is consistent with transport simulations reported by Fast et al. (2012). As background SOA would be aged, its presence is consistent with the O to C ratios reported by Shilling et al. (2013). Correlations between background $\mathrm{OA}$ and its precursors, in particular the strong correlation with background $\mathrm{CH}_{3} \mathrm{OH}$ and weak correlation with background $\mathrm{CO}$, suggest that background $\mathrm{OA}$ is primarily biogenic. Background aerosol will foster the formation of OA in the Sacramento plume by more than doubling the aerosol volume potentially available for gas to particle partitioning. The increase in partitioning realized will depend on the volatility of gas phase precursors and aerosol viscosity and phase (e.g., Zaveri et al., 2014; Madronich et al., 2015). In so far as isoprene and its oxidation products are expected to dominant VOC reactivity, these compounds will affect the processing of anthropogenic carbon and may be seen as contributing to A-B interactions.
The circumstance that $\sim 60 \%$ of peak OA is background, and appears to be primarily biogenic, has the consequence that the fraction of non-fossil carbon in the Sacramento plume will be significantly greater than half, especially since plume OA is partially biogenic and approximately $20-30 \%$ of urban anthropogenic emissions are estimated to be from non-fossil sources, such as cooking, trash burning, and biofuel use (Hodzic et al., 2011; Zotter et al., 2014). There were no ${ }^{14} \mathrm{C}$ measurements to compare with our correlation-based predictions, but given observations in areas with lower biogenic emission rates (Marley et al., 2009), and given observations made at Blodgett Forest (Worton et al., 2011), it would be surprising if non-fossil carbon did not predominate.

\section{Conclusions}

We have used aircraft observations obtained during the CARES field campaign to infer whether background OA and OA produced in the Sacramento plume are primarily anthropogenic or biogenic, whether there is enhanced OA formation caused by interactions between anthropogenic and biogenic compounds, and if observations are consistent with ${ }^{14} \mathrm{C}$ measurements from other locations. Linear and bilinear correlations for 56 individual transects show how well OA follows explanatory variables over small spatial scales, whilst correlations amongst transects yield information on how $\triangle \mathrm{OA}$ (plume perturbation) varies due to changes in location and day-to-day variations in meteorological conditions. Following Setyan et al. (2012) and Shilling et al. (2013), transects are split into subsets in order to determine whether high OA concentrations are uniquely associated with high mixing ratios of anthropogenic and biogenic tracers.

Explanatory variables were $\mathrm{CO}$ as a tracer of anthropogenic OA precursors and isoprene, MVK+MACR, and $\mathrm{CH}_{3} \mathrm{OH}$ as tracers of biogenic emissions. In addition $\mathrm{O}_{3}$ was used as a surrogate for photochemical activity. Tracers should ideally have lifetimes comparable to the timescales over which $\mathrm{OA}$ is formed. $\mathrm{CO}$ is long lived. $\mathrm{CH}_{3} \mathrm{OH}$ is used here (to the best of our knowledge, for the first time) as an analogous long-lived biogenic tracer with an atmospheric lifetime of $\sim 10$ days. In contrast, isoprene and $\mathrm{MVK}+\mathrm{MACR}$ have lifetimes ranging from less than an hour to a few hours.

We have found that

1. Linear and bilinear regression models indicate that most of the explained variance in $\mathrm{OA}$ is explained by $\mathrm{CO}$ rather than a biogenic compound. This is true for within transect and amongst transect correlations. Adding a biogenic tracer to OA vs. CO to yield a bilinear model results in only a modest increase in explained variance.

2. Anthropogenic and biogenic tracers were often correlated, possibly due to common effects of meteorology and chance geographic alignment of sources. Spurious 
correlations between $\mathrm{OA}$ and explanatory variables necessitate the use of multivariate models.

3. The correlation between $\triangle \mathrm{OA}$ and $\Delta \mathrm{O}_{3}\left(R^{2}=0.88\right)$ agrees with the findings of Herndon et al. (2008) and Wood et al. (2010) that there is a common rate limiting step for production of $\mathrm{O}_{3}$ and SOA within an urban plume.

4. The excellent correlation between background OA and background $\mathrm{CH}_{3} \mathrm{OH}\left(R^{2}=0.82\right)$ and the low correlation with background $\mathrm{CO}\left(R^{2}=0.24\right)$ is consistent with a biogenic origin for background OA. This comparison requires a long-lived biogenic tracer as the measured isoprene or MVK + MACR backgrounds are unlikely to have been present when the background OA was formed. As such they show little correlation.

5. Background OA is on average $60 \%$ of peak OA. On the basis of background OA being primarily of biogenic origin and SOA formed downwind of Sacramento deriving primarily from anthropogenic carbon, a fraction of which is non-fossil, it is predicted that OA found in the Sacramento plume would be mostly non-fossil.

6. Evidence for $\mathrm{A}-\mathrm{B}$ interaction comes from comparing $\triangle \mathrm{OA}$ between data subsets having different combinations of low and high mixing ratios of anthropogenic and biogenic tracers. We are able to reproduce the findings of Setyan et al. (2012) and Shilling et al. (2013) that high values of OA only occur when anthropogenic and biogenic compounds both have a high mixing ratio. Differences in precursor abundance between data subsets should be taken into account to determine what portion of OA can be attributed to A-B interactions. Doing so by using residuals from a bilinear fit to the amongst transect data set, yields estimates that A-B interactions can increase $\mathrm{OA}$ concentration by a factor of 1.2 to 1.5 depending on the compound used as a tracer of biogenic emissions. This increase is relative to the bilinear relation describing data not in the high CO-high Bio subset. A-B interactions up to a factor of 3.6 are obtained from a fit to coarser subset-averaged data.

7. The data subset with high values of anthropogenic and biogenic precursors is dominated by two flights on the last day of the field campaign. Temperature reached $40^{\circ} \mathrm{C}$ and wind speed was $\sim 2 \mathrm{~m} \mathrm{~s}^{-1}$. Concentrations of $\mathrm{OA}, \mathrm{O}_{3}$, and biogenic trace gases were the highest recorded, and $\mathrm{CO}$ was close to the highest recorded. In addition to the many mechanisms for $\mathrm{A}-\mathrm{B}$ interactions described in the literature (e.g. Carlton et al., 2010; Hoyle et al., 2011; Xu et al., 2015) it is useful to consider whether additional mechanisms are enabled during a pollution episode such as what occurred on 28 June. Poor ventilation and high temperatures lead to increased biogenic emissions, higher ambient amounts of biogenic and anthropogenic SOA precursors, and increased photochemical activity as evidenced by a higher $\mathrm{O}_{3}$ mixing ratio, the latter requiring the presence of anthropogenic $\mathrm{NO}_{x}$. Thus, the highest SOA concentrations are likely to occur coincident with elevated mixing ratios of both anthropogenic and biogenic tracers.

By its very nature conclusions based on correlations are inferential. It would be highly desirable to test our results against a high-resolution chemical transport model. Model calculations are essential for comparisons between CARES and other regions; in particular, the well-studied eastern USA in which aerosols have higher relative and absolute amounts of inorganic constituents and there is a greater abundance of liquid water, perhaps enabling $\mathrm{A}-\mathrm{B}$ mechanisms to a greater extent than observed in the CARES region.

\section{Copyright statement}

The author's copyright for this publication is transferred to US Government.

\section{The Supplement related to this article is available online at doi:10.5194/acp-16-1729-2016-supplement.}

Acknowledgements. We thank chief pilot Bob Hannigan and the flight crew from PNNL for a job well done. We gratefully acknowledge the Atmospheric Radiation Measurement (ARM) and the Atmospheric Systems Research (ASR) Programs within the Office of Biological and Environmental Research of the Office of Science of the US Department of Energy (DOE) for supporting field and analysis activities and for providing the G-1 aircraft. Support for J. Fast, J. Hubbe, J. Shilling, and R. Zaveri of Pacific Northwest National Laboratory and Q. Zhang of U. C. Davis was provided by the US DOE under contracts DE-A06-76RLO 1830 and DE-SC0007178, respectively. Research by L. Kleinman, C. Kuang, A. Sedlacek, G. Senum, S. Springston, and J. Wang of Brookhaven National Laboratory was performed under sponsorship of the US DOE under contracts DE-SC0012704.

This research was performed under the auspices of the United States Department of Energy under contract no. DE-SC0012704.

Edited by: G. McFiggans

\section{References}

Canagaratna, M. R., Jayne, J. T., Jimenez, J. L., Allan, J. D., Alfarra, M. R., Zhang, Q., Onasch, T. B., Drewnick, F., Coe, H., Middlebrook, A., Delia, A., Williams, L. R., Trimborn, A. M., Northway, M. J., DeCarlo, P. F., Kolb, C. E., Davidovits, P., and Worsnop, D. R.: Chemical and Microphysical Characterization of Ambient Aerosols with the Aerodyne Aerosol Mass Spectrometer, Mass Spectrom. Rev., 26, 185-222, 2007. 
Carlton, A. G. and Turpin, B. J.: Particle partitioning potential of organic compounds is highest in the Eastern US and driven by anthropogenic water, Atmos. Chem. Phys., 13, 10203-10214, doi:10.5194/acp-13-10203-2013, 2013.

Carlton, A. G., Wiedinmyer, C., and Kroll, J. H.: A review of Secondary Organic Aerosol (SOA) formation from isoprene, Atmos. Chem. Phys., 9, 4987-5005, doi:10.5194/acp-9-4987-2009, 2009.

Carlton, A. G., Pinder, R. W., Bhave, P. V., and Pouliot, G. A.: To What Extent Can Biogenic SOA be Controlled?, Environ. Sci. Technol., 44, 3376-3380, doi:10.1021/es903506b, 2010.

Chen, Q., Farmer, D. K., Schneider, J., Zorn, S. R., Heald, C. L., Farl, T. G., Guenther, A., Allan, J. D., Robinson, N., Coe, H., Kimmel, J. R., Pauliquevis, T., Borrmann, S., Pöschl, U., Andreae, M. O., Artaxo, P., Jimenez, J. L., and Martin, S. T.: Mass spectral characterization of submicron biogenic organic particles in the Amazon Basin, Geophys. Res. Lett., 36, L20806, doi:10.1029/2009GL039880, 2009.

de Gouw, J. and Jimenez, J. L.: Organic Aerosols in the Earth's Atmosphere, Environ. Sci. Technol., 43, 7614-7618, 2009.

de Gouw, J. A., Middlebrook, A. M., Warneke, C., Goldan, P. D., Kuster, W. C., Roberts, J. M., Fehsenfeld, F. C., Worsnop, D. R., Canagaratna, M. R., Pszenny, A. A. P., Keene, W. C., Marchewka, M., Bertman, S. B., and Bates, T. S.: Budget of organic carbon in a polluted atmosphere: Results from the New England Air Quality Study in 2002, J. Geophys. Res., 110, D16305, doi:10.1029/2004JD005623, 2005.

de Gouw, J. A., Brock, C. A., Atlas, E. L., Bates, T. S., Fehsenfeld, F. C., Goldan, P. D., Holloway, J. S., Kuster, W. C., Lerner, B. M., Matthew, B. M., Middlebrook, A. M., Onasch, T. B., Peltier, R. E., Quinn, P. K., Senff, C. J., Stohl, A., Sullivan, A. P., Trainer, M., Warneke, C., Weber, R. J., and Williams, E. J.: Sources of particulate matter in the northeastern United States in summer: 1.Direct emissions and secondary formation of organic matter in urban plumes, J. Geophys. Res.-Atmos., 113, D08301, doi:10.1029/2007jd009243, 2008.

Dreyfus, G. B., Schade, G. W., and Goldstein, A. H.: Observational constraints on the contribution of isoprene oxidation to ozone production on the western slope of the Sierra Nevada, California, J. Geophys. Res., 107, 4365, doi:10.1029/2001JD001490, 2002.

Ervens, B., Turpin, B. J., and Weber, R. J.: Secondary organic aerosol formation in cloud droplets and aqueous particles (aqSOA): a review of laboratory, field and model studies, Atmos. Chem. Phys., 11, 11069-11102, doi:10.5194/acp-1111069-2011, 2011.

Fast, J. D., Gustafson Jr., W. I., Berg, L. K., Shaw, W. J., Pekour, M., Shrivastava, M., Barnard, J. C., Ferrare, R. A., Hostetler, C. A., Hair, J. A., Erickson, M., Jobson, B. T., Flowers, B., Dubey, M. K., Springston, S., Pierce, R. B., Dolislager, L., Pederson, J., and Zaveri, R. A.: Transport and mixing patterns over Central California during the carbonaceous aerosol and radiative effects study (CARES), Atmos. Chem. Phys., 12, 1759-1783, doi:10.5194/acp-12-1759-2012, 2012.

Goldstein, A. H., Koven, C. D., Heald, C. L., and Fung, I. Y.: Biogenic carbon and anthropogenic pollutants combine to form a cooling haze over the southeastern United States, P. Natl. Acad. Sci., 106, 8835-8840, 2009.

Guenther, A., Hewitt, C.N., Erickson, D., Fall, R., Geron, C., Graedel, T., Harley, P., Klinger, L., Lerdau, M., McKay, W. A.,
Pierce, T., Scholes, B., Steinbrecher, R., Tallamraju, R., Taylor, T., and Zimmerman, P.: A global model of natural volatile organic compound emission, J. Geophys. Res., 100, 8873-8892, 1995.

Guenther, A. B., Zimmerman, P. R., Harley, P. C., Monson, R. K., and Fall, R.: Isoprene and monoterpene emission rate variability: Model evaluations and sensitivity analysis, J. Geophys. Res., 98, 12609-12617, 1993.

Herndon, S. C., Onasch, T. B., Wood, E. C., Kroll, J. H., Canagaratna, M. R., Jayne, J. T., Zavala, M. A., Knighton, W. B., Mazzoleni, C., Dubey, M. K., Ulbrich, I. M., Jimenez, J. L., Seila, R., de Gouw, J. A., de Foy, B., Fast, J., Molina, L. T., Kolb, C. E., and Worsnop, D. R.: Correlation of secondary organic aerosol with odd oxygen in Mexico City, Geophys. Res. Lett., 35, L15804, doi:10.1029/2008GL034058, 2008.

Hodzic, A., Jimenez, J. L., Prévôt, A. S. H., Szidat, S., Fast, J. D., and Madronich, S.: Can 3-D models explain the observed fractions of fossil and non-fossil carbon in and near Mexico City?, Atmos. Chem. Phys., 10, 10997-11016, doi:10.5194/acp10-10997-2010, 2010.

Hoyle, C. R., Boy, M., Donahue, N. M., Fry, J. L., Glasius, M., Guenther, A., Hallar, A. G., Huff Hartz, K., Petters, M. D., Petäjä, T., Rosenoern, T., and Sullivan, A. P.: A review of the anthropogenic influence on biogenic secondary organic aerosol, Atmos. Chem. Phys., 11, 321-343, doi:10.5194/acp-11-321-2011, 2011.

Kanakidou, M., Tsigaridis, K., Dentener, F. J., and Crutzen, P. J.: Human-activity enhanced formation of organic aerosols by biogenic hydrocarbon oxidation, J. Geophys. Res., 105, 9243-9254, 2000.

Kleinman, L. I., Springston, S. R., Wang, J., Daum, P. H., Lee, Y.-N., Nunnermacker, L. J., Senum, G. I., Weinstein-Lloyd, J., Alexander, M. L., Hubbe, J., Ortega, J., Zaveri, R. A., Canagaratna, M. R., and Jayne, J.: The time evolution of aerosol size distribution over the Mexico City plateau, Atmos. Chem. Phys., 9, 4261-4278, doi:10.5194/acp-9-4261-2009, 2009.

Lindinger, W., Hansel, A., and Jordan, A.: On-line monitoring of volatile organic compounds at pptv levels by means of proton transfer-reaction mass spectrometry (PTR-MS) - Medical applications, food control and environmental research, Int. J. Mass Spectrom., 173, 191-241, 1998.

Madronich, S., Conley, A., Lee-Taylor, J., Kleinman, L., Hodzic, A., and Aumont, B.: Non-linear partitioning and organic volatility distributions of urban aerosols, Faraday Discuss., doi:10.1039/C5FD00209E, online first, 2015.

Marley, N. A., Gaffney, J. S., Tackett, M., Sturchio, N. C., Heraty, L., Martinez, N., Hardy, K. D., Marchany-Rivera, A., Guilderson, T., MacMillan, A., and Steelman, K.: The impact of biogenic carbon sources on aerosol absorption in Mexico City, Atmos. Chem Phys., 9, 1537-1549, doi:10.5194/acp-9-1537-2009, 2009.

Matsui, H., Koike, M., Takegawa, N., Kondo, Y., Griffin, R. J., Miyazaki, Y., Yokouchi, Y., and Ohara, T.: Secondary Organic Aerosol Formation in Urban Air: Temporal Variations and Possible Contributions from Unidentified Hydrocarbons, J. Geophys Res.-Atmos., 114, D04201, doi:10.1029/2008JD010164, 2009.

Ng, N. L., Kroll, J. H., Keywood, M. D., Bahreini, V. V., Flagan, R. C., and Seinfeld, J. H.: Contribution of first- versus second generation organic aerosols formed in the oxidation of biogenic hydrocarbons, Environ. Sci. Technol., 40, 2283-2397, 2006. 
Panofsky, H. A. and Brier, G. W.: Some Applications of Statistics to Meteorology, The Pennsylvania State University, University Park, PA, 1968.

Robinson, A. L., Donahue, N. M., Shrivastava, M. K., Weitkamp, E. A., Sage, A. M., Grieshop, A. P., Lane, T. E., Pierce, J. R., and Pandis, S. N.: Rethinking organic aerosols: Semivolatile emissions and photochemical aging, Science, 315, 1259-1262, doi:10.1126/science.1133061, 2007.

Schade, G. W. and Goldstein, A. H.: Seasonal measurements of acetone and methanol: Abundances and implications for atmospheric budgets, Global Biogeochem. Cy., 20, GB1011, doi:10.1029/2005GB002566, 2006.

Schichtel, B. A., Malm, W. C., Bench, G., Fallon, S., McDade, C. E., Chow, J. C., and Watson, J. G.: Fossil and contemporary fine particulate carbon fractions at 12 rural and urban sites in the united states, J. Geophys. Res.-Atmos., 113, D02311, doi:10.1029/2007jd008605, 2008.

Setyan, A., Zhang, Q., Merkel, M., Knighton, W. B., Sun, Y., Song, C., Shilling, J. E., Onasch, T. B., Herndon, S. C., Worsnop, D. R., Fast, J. D., Zaveri, R. A., Berg, L. K., Wiedensohler, A., Flowers, B. A., Dubey, M. K., and Subramanian, R.: Characterization of submicron particles influenced by mixed biogenic and anthropogenic emissions using high-resolution aerosol mass spectrometry: results from CARES, Atmos. Chem. Phys., 12, 8131-8156, doi:10.5194/acp-12-8131-2012, 2012.

Shilling, J. E., Zaveri, R. A., Fast, J. D., Kleinman, L., Alexander, M. L., Canagaratna, M. R., Fortner, E., Hubbe, J. M., Jayne, J. T., Sedlacek, A., Setyan, A., Springston, S., Worsnop, D. R., and Zhang, Q.: Enhanced SOA formation from mixed anthropogenic and biogenic emissions during the CARES campaign, Atmos. Chem. Phys., 13, 2091-2113, doi:10.5194/acp-13-20912013, 2013.

Sillman, S. and Samson, P. J.: Impact of temperature on oxidant photochemistry in urban, polluted rural and remote environments, J. Geophys. Res., 100, 11497-11508, doi:10.1029/94JD02146, 1995.

Slowik, J. G., Stroud, C., Bottenheim, J. W., Brickell, P. C., Chang, R. Y.-W., Liggio, J., Makar, P. A., Martin, R. V., Moran, M. D., Shantz, N. C., Sjostedt, S. J., van Donkelaar, A., Vlasenko, A., Wiebe, H. A., Xia, A. G., Zhang, J., Leaitch, W. R., and Abbatt, J. P. D.: Characterization of a large biogenic secondary organic aerosol event from eastern Canadian forests, Atmos. Chem. Phys., 10, 2825-2845, doi:10.5194/acp-10-2825-2010, 2010.

Spracklen, D. V., Jimenez, J. L., Carslaw, K. S., Worsnop, D. R., Evans, M. J., Mann, G. W., Zhang, Q., Canagaratna, M. R., Allan, J., Coe, H., McFiggans, G., Rap, A., and Forster, P.: Aerosol mass spectrometer constraint on the global secondary organic aerosol budget, Atmos. Chem. Phys., 11, 12109-12136, doi:10.5194/acp-11-12109-2011, 2011.

Steiner, A. L., Tonse, S., Cohen, R. C., Goldstein, A. H., and Harley, R. A.: Influence of future climate and emissions on regional air quality in California, J. Geophys. Res., 111, D18303, doi:10.1029/2005JD006935, 2006.

Steiner, A. L., Davis, A. J., Sillman, S., Owen, R. C., Michalak, A. M., and Fiore, A. M.: Observed suppression of ozone formation at extremely high temperatures due to chemical and biophysical feedbacks, P. Natl. Acad. Sci., 107, 19685-19690, 2010.

Sullivan, A. P., Peltier, R. E., Brock, C. A., de Gouw, J. A., Holloway, J. S., Warneke, C., Wollny, A. G., and Weber, R. J.: Air- borne measurements of carbonaceous aerosol soluble in water over northeastern United States: Method development and an investigation into water-soluble organic carbon sources, J. Geophys. Res., 111, D23S46, doi:10.1029/2006JD007072, 2006.

Thiébaux, H. J. and Zwiers, F. W.: The interpretation and estimation of effective sample size, J. Clim. Appl. Meteorol., 23, 800-811, 1984.

Trenberth, K. E.: Some effects of finite sample size and persistence on meteorological statistics, Part 1: Autocorrelation, Mon. Weather Rev., 112, 2359-2368, 1984.

Tunved, P., Hansson, H.-C., Kerminen, V.-M., Strom, J., Dal Maso, M., Lihavainen, H., Viisaned, Y., Aalto, P. P., Kpmppula, M., and Kulmala, M.: High natural aerosol loading over boreal forests, Science, 312, 261-263, doi:10.1126/science.1123052, 2006.

Volkamer, R., Jimenez, J. L., San Martini, F., Dzepina, K., Zhang, Q., Salcedo, D., Molina, L. T., Worsnop, D. R., and Molina, M. J.: Secondary organic aerosol formation from anthropogenic air pollution: Rapid and higher than expected, Geophys. Res. Lett., 33, L17811, doi:10.1029/2006GL026899, 2006.

Weber, R. J., Sullivan, A. P., Peltier, R. C., Russell, A., Yan, B., Zheng, M., de Gouw, J., Warnke, C., Brock, C., Holloway, J. S., Atlas, E. L., and Edgerton, E.: A study of secondary organic aerosol formation in the anthropogenicinfluenced southeastern United States, J. Geophys. Res., 112, D13302, doi:10.1029/2007JD008408, 2007.

Wells, K. C., Millet, D. B., Hu, L., Cady-Pereira, K. E., Xiao, Y., Shephard, M. W., Clerbaux, C. L., Clarisse, L., Coheur, P.F., Apel, E. C., de Gouw, J., Warneke, C., Singh, H. B., Goldstein, A. H., and Sive, B. C.: Tropospheric methanol observations from space: retrieval evaluation and constraints on the seasonality of biogenic emissions, Atmos. Chem. Phys., 12, 5897-5912, doi:10.5194/acp-12-5897-2012, 2012.

Wood, E. C., Canagaratna, M. R., Herndon, S. C., Onasch, T. B., Kolb, C. E., Worsnop, D. R., Kroll, J. H., Knighton, W. B., Seila, R., Zavala, M., Molina, L. T., DeCarlo, P. F., Jimenez, J. L., Weinheimer, A. J., Knapp, D. J., Jobson, B. T., Stutz, J., Kuster, W. C., and Williams, E. J.: Investigation of the correlation between odd oxygen and secondary organic aerosol in Mexico City and Houston, Atmos. Chem. Phys., 10, 8947-8968, doi:10.5194/acp-10-8947-2010, 2010.

Worton, D. R., Goldstein, A. H., Farmer, D. K., Docherty, K. S., Jimenez, J. L., Gilman, J. B., Kuster, W. C., de Gouw, J., Williams, B. J., Kreisberg, N. M., Hering, S. V., Bench, G., McKay, M., Kristensen, K., Glasius, M., Surratt, J. D., and Seinfeld, J. H.: Origins and composition of fine atmospheric carbonaceous aerosol in the Sierra Nevada Mountains, California, Atmos. Chem. Phys., 11, 10219-10241, doi:10.5194/acp-1110219-2011, 2011.

Xu, L., Guo, H., Boyd, C. M., Klein, M., Bougiatioti, A., Cerully, K. M., Hite, J. R., Isaacman-VanWertz, G., Kreisberg, N. M., Knote, C., Olson, K., Koss, A., Goldstein, A. H., Hering, S. V., de Gouw, J., Baumann, K., Lee, S. H., Nenes, A., Weber, R. J., and Lee, N. L.: Effects of anthropogenic emissions on aerosol formation from isoprene and monoterpenes in the southeastern United States, P. Natl. Acad. Sci., 112, 37-42, doi:10.1073/pnas.1417609112, 2015.

Zaveri, R. A., Shaw, W. J., Cziczo, D. J., Schmid, B., Ferrare, R. A., Alexander, M. L., Alexandrov, M., Alvarez, R. J., Arnott, W. P., Atkinson, D. B., Baidar, S., Banta, R. M., Barnard, J. C., Be- 
ranek, J., Berg, L. K., Brechtel, F., Brewer, W. A., Cahill, J. F., Cairns, B., Cappa, C. D., Chand, D., China, S., Comstock, J. M., Dubey, M. K., Easter, R. C., Erickson, M. H., Fast, J. D., Floerchinger, C., Flowers, B. A., Fortner, E., Gaffney, J. S., Gilles, M. K., Gorkowski, K., Gustafson, W. I., Gyawali, M., Hair, J., Hardesty, R. M., Harworth, J. W., Herndon, S., Hiranuma, N., Hostetler, C., Hubbe, J. M., Jayne, J. T., Jeong, H., Jobson, B. T., Kassianov, E. I., Kleinman, L. I., Kluzek, C., Knighton, B., Kolesar, K. R., Kuang, C., Kubátová, A., Langford, A. O., Laskin, A., Laulainen, N., Marchbanks, R. D., Mazzoleni, C., Mei, F., Moffet, R. C., Nelson, D., Obland, M. D., Oetjen, H., Onasch, T. B., Ortega, I., Ottaviani, M., Pekour, M., Prather, K. A., Radney, J. G., Rogers, R. R., Sandberg, S. P., Sedlacek, A., Senff, C. J., Senum, G., Setyan, A., Shilling, J. E., Shrivastava, M., Song, C., Springston, S. R., Subramanian, R., Suski, K., Tomlinson, J., Volkamer, R., Wallace, H. W., Wang, J., Weickmann, A. M., Worsnop, D. R., Yu, X.-Y., Zelenyuk, A., and Zhang, Q.: Overview of the 2010 Carbonaceous Aerosols and Radiative Effects Study (CARES), Atmos. Chem. Phys., 12, 7647-7687, doi:10.5194/acp-12-7647-2012, 2012.

Zaveri, R. A., Easter, R. C., Shilling, J. E., and Seinfeld, J. H.: Modeling kinetic partitioning of secondary organic aerosol and size distribution dynamics: representing effects of volatility, phase state, and particle-phase reaction, Atmos. Chem. Phys., 14, 5153-5181, doi:10.5194/acp-14-5153-2014, 2014.
Zhang, Q., Worsnop, D. R., Canagaratna, M. R., and Jimenez, J. L.: Hydrocarbon-like and oxygenated organic aerosols in Pittsburgh: insights into sources and processes of organic aerosols, Atmos. Chem. Phys., 5, 3289-3311, doi:10.5194/acp-5-32892005, 2005.

Zhang, Q., Jimenez, J. L., Canagaratna, M. R., Allan, J. D., Coe, H., Ulbrich, I., Alfarra, M. R., Takami, A., Middlebrook, A. M., Sun, Y. L., Dzepina, K., Dunlea, E., Docherty, K., DeCarlo, P. F., Salcedo, D., Onasch, T., Jayne, J. T., Miyoshi, T., Shimono, A., Hatakeyama, S., Takegawa, N., Kondo, Y., Schneider, J., Drewnick, F., Weimer, S., Demerjian, K., Williams, P., Bower, K., Bahreini, R., Cotrell, L., Griffin, R. J., Rautiainen, J., Sun, J. Y., Zhang, Y. M., and Worsnop, D. R.: Ubiquity and dominance of oxygenated species in organic aerosols in anthropogenicallyinfluenced northern hemisphere mid-latitudes, Geophys. Res. Lett., 34, L13801, doi:10.1029/2007GL029979, 2007.

Zotter, P., El-Haddad, I., Zhang, Y., Hayes, P. L., Zhang, X., Lin, Y.-H., Wacker, L., Schnelle-Kreis, J., Abbaszade, G., Zimmermann, R., Surratt, J. D., Webster, R., Jimenez, J. L., Szidat, S., Baltensperger, U., and Prévôt, A. S. H.: Diurnal cycle of fossil and nonfossil carbon using radiocarbon analyses during CalNex, J. Geophys. Res., 119, 6818-6835, doi:10.1002/2013JD021114, 2014. 